\title{
Ecological, topographic and successional patterns across wetlands in a rugged land uplift coast in Nyby, northern Finland
}

\author{
JARMO LAITINEN, JARI OKSANEN, TUIJA MALINIEMI, EERO KAAKINEN, KAISU AAPALA AND \\ SAKARI REHELL
}

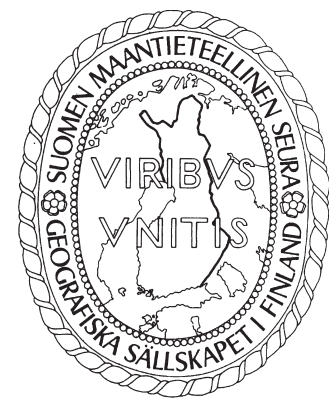

Laitinen, Jarmo, Jari Oksanen, Tuija Maliniemi, Eero Kaakinen, Kaisu Aapala \& Sakari Rehell (2016). Ecological, topographic and successional patterns across wetlands in a rugged land uplift coast in Nyby, northern Finland. Fennia 194: 1, 89-116. ISSN 1798-5617.

We studied 45 mid-boreal wetlands in a rugged land uplift coast with a thin cover of till. Wetlands ranged from 1 to $53 \mathrm{~m}$ a.s.l. and were of highly various sizes. Our aims were to examine, if vegetation types are valid in comparing wetlands, what kind of ecological major pattern the vegetation type composition of wetlands shows and how vegetation types distribute across altitudes. On those ground we discuss the wetland succession of the study area. We used the Finnish mire site types as vegetation types. Mire site types could be used for an ecological classification and ordination of the wetlands. As was expected, the major gradient consisted of the transition from mire margin (swamp) to expanse. The distribution of the Major Vegetational Wetland Groups (MVWG) responded to a general water-flow pattern in the landscape. Partly different peatland succession sequences occur in areas with small mire basins and in areas with larger mire basins with evolving mire complexes. Sequences of small wetlands and those of mire complexes follow the same trajectory only as far as the major gradient is considered while they differ with regard to the vegetation type composition of locally rare vegetation types and with regard to peatland morphology. Trajectories of mire complexes at catchment divides differ from those at catchment centers where the waters in the landscape tend to gather. Peatland forms of aapa mires experience a change reaching altitudes of 30-50 m a.s.l. Small bog complexes at catchment divides reach a stage of an unpatterned Sphagnum fuscum bog in the study area. Mature mixed complexes with aapa-mire parts and patterned sloping-bog parts only occur at altitudes higher than $60 \mathrm{~m}$ a.s.l. Peculiarities in the succession of the wetlands of Nyby, which include the presence of separate incomplete successional sequences in the same area, are mainly caused by the peculiar topography with various sub-areas and with an abundance of rock outcrops.

Keywords: Gulf of Bothnia, vegetation survey, cluster analysis, aapa mires, mire site types, peatland forms

Jarmo Laitinen, Jari Oksanen \& Tuija Maliniemi, University of Oulu, Department of Ecology, PO Box 3000, FIN 90014, Finland.E-mail: jarmo.laitinen@oulu.fi, jari. oksanen@oulu.fi, tuija.maliniemi@oulu.fi

Eero Kaakinen, Kurkelantie1 D 38 Oulu,Finland.E-mail: eero.kaakinen@dnainternet.net

Kaisu Aapala, Finnish Environment Institute, PO Box 140, 00251, Helsinki, Finland. E-mail: kaisu.aapala@ymparisto.fi

Sakari Rehell, Metsähallitus, PO Box 81, Veteraanikatu 5, FI 90101 Oulu, Finland. E-mail: sakari.rehell@metsa.fi

\section{Introduction}

Boreal landscape is characterized by coniferous forests and peatlands. From south- to mid-boreal
(Hämet-Ahti 1981) lowlands around the northern part of the Baltic Sea, the Gulf of Bothnia, new landscape is emerging from the sea as a result of the glacio-isostatic land uplift. Associated primary 
succession on uplands leads to various types of forests (Svensson \& Jeglum 2000) and succession on depressions to ponds and various types of peatlands (Brandt 1948; Rehell \& Heikkilä 2009). The coasts of the Gulf of Bothnia in the glaciated shield area differ topographically. In general terms, the western (Swedish) side of the Gulf of Bothnia has a more rugged coast with a steeper general gradient of the ground surface near the sea level and the eastern (Finnish) side has a gentler gradient from the seaside far to the inland (Seppälä 2005). Bedrock topography ultimately determines the major lines for landforms, including the size and proportion of depressions occupied by wetlands in the emerging landscape, and topographically different coasts provide different prerequisites for wetland succession. This has not been much stressed in botanical peatland studies in general. The bedrock topography has a special prominent role for the landforms of Nyby study area with a thin and discontinuous cover of till (Alalammi 1990). Recent investigations for conservation purposes in Finland (Kaakinen et al. 2008) and partly old work (Aario 1932) concentrate on the vegetation and succession of mires in median to large bedrock basins with evolving mire complexes, while the vegetation and the succession of mires in small depressions are partly ignored (see Lindholm 2013a). This implies that possible differences between the succession of small wetlands among rugged topography and the succession of wetlands into mire complexes among flatter topography are not specifically studied. Classic works on boreal mires on the land uplift coast provide a basic information about the historic and morphologic characteristics of a mature ombrotrophic mire complex type in a southboreal area (Aario 1932), about vegetation stages along the succession of small swamps to fens and to bogs in a south-boreal area (Brandt 1948) and about the plant communities, gradients and ecology of low-altitude mires in a mid-boreal coastal rich fen area (Elveland 1976). Recent research on mire succession in northern Finnish coast, on the one hand, aims to study specific patterns for the relationships of the vegetation and topography at different scales (Rehell \& Heikkilä 2009; Rehell et al. 2012a, 2012b), and research of another kind, on the other hand, focuses on general functioning of boreal successional mire ecosystems, especially applying research on gas exchange (e.g. Leppälä 2011). The study of Tuittila et al. (2013) suggests using spatial age transects as a model of vertical peatland formation. Similarity of certain degree was found between the current spatial vegetation gradient in peatland succession and the vertical temporal vegetation gradient observed in the oldest peatland in the same study area. Walker et al. (2010), however, warn of a false use of chronosequences stating that they are often used inappropriately, leading to false conclusions about ecological patterns and processes.

Mid-boreal wetlands of Nyby in northern Finland provide a group of mineral wetlands (small reed marshes) and peatlands (small mires and mire complexes, mainly aapa mires) on the northeast coast of the Gulf of Bothnia, where a small area topographically resembles a typical (more rugged) Swedish coast more than a typical Finnish coast. Small wetlands among rugged bedrock topography with a thin and discontinuous cover of till near the sea and some larger wetlands among slightly flatter bedrock topography in the inland provide a suitable object for a survey on the variety of wetlands.

We consider the mire succession in terms of the change in the vegetation type composition and peatland topography, and hypothesize that the succession of small mires and aapa mires differ in those respects. We additionally suppose that the succession of peatlands building up mire complexes near catchment divides is different from the succession of peatlands at catchment centers, in which the rates of the water flow and the supply of nutrients are higher than at catchment peripheries (Ivanov 1981; Seppä 2002). In this study we have several aims. First, are the Finnish mire vegetation types valid as data for analyzing differences between wetlands generally and for successional wetlands on the land uplift coast specifically. Second, we approach the ecological-hydrological pattern across Nyby wetlands asking (a) what is the major vegetation (type) gradient for the whole group of studied Nyby wetlands, (b) do the major vegetational wetland groups relate to the altitude gradient and to wetland sizes, and (c) do they relate to a landscape-level water-flow pattern. Third, we ask how vegetation types with different climatic focus are distributed along the altitude gradient and across local topographic groups of wetlands. Fourth, we discuss the peatland succession of Nyby and boreal regions generally asking (a) does the succession of wetlands in small bedrock basins differ, and how, from that of mires in larger bedrock basins, and (b) what kind of trajectories occur in the succession of mire complexes and what are the ultimate causes for those trajectories. 


\section{Study area and field work}

The study area is located in the mid-boreal (HämetAhti 1981) lowlands of Fennoscandia, ranging from the seaside to the altitude of about $55 \mathrm{~m}$ a.s.l. (Fig. 1). Wetlands of Nyby, as called in this research, refer to wetlands of highly various sizes (0.1-185 ha) on the northeast coast of the Bothnian Bay. Climatic conditions are practically constant across the whole study area. As counted from an interpolated European climatic data (Haylock et al. 2008), the mean annual temperature is 1-4 ${ }^{\circ} \mathrm{C}$, average $2.5^{\circ} \mathrm{C}$, and the mean annual precipitation is $400-700 \mathrm{~mm}$, average $500 \mathrm{~mm}$, for Nyby area (1980-2010). The basal gneiss area runs to the seaside around Nyby (Alalammi 1990). Glacioisostatic land uplift ranges from 7 to $8 \mathrm{~mm}$ in a year (Taipale \& Saarnisto 1991). The study area situates below the highest Holocene coastline. Nyby area differs from the surroundings in having rock outcrops (bedrock terrain, Alalammi 1990) and varying topography with relatively small mire basins. The $2.5 \mathrm{~km}$ wide belt at the seaside north of Nyby is most sloping and forms a threshold in the topography. Moreover, the mire basins are the smallest of all within the study area. There is only one short stretch of an esker in the area (Alalammi 1990). Relatively high lowland altitudes, the level of 50-60 m a.s.l., are reached in a horizontal distance shorter than in any other district in the Finnish coasts. The study area belongs to the southern aapa mire zone (Ruuhijärvi \& Hosiaisluoma 1988). Peatlands cover $40 \%$ of the land area, and only about one fourth of the peatland is drained, while in the surroundings the proportion of drained peatlands is much larger.

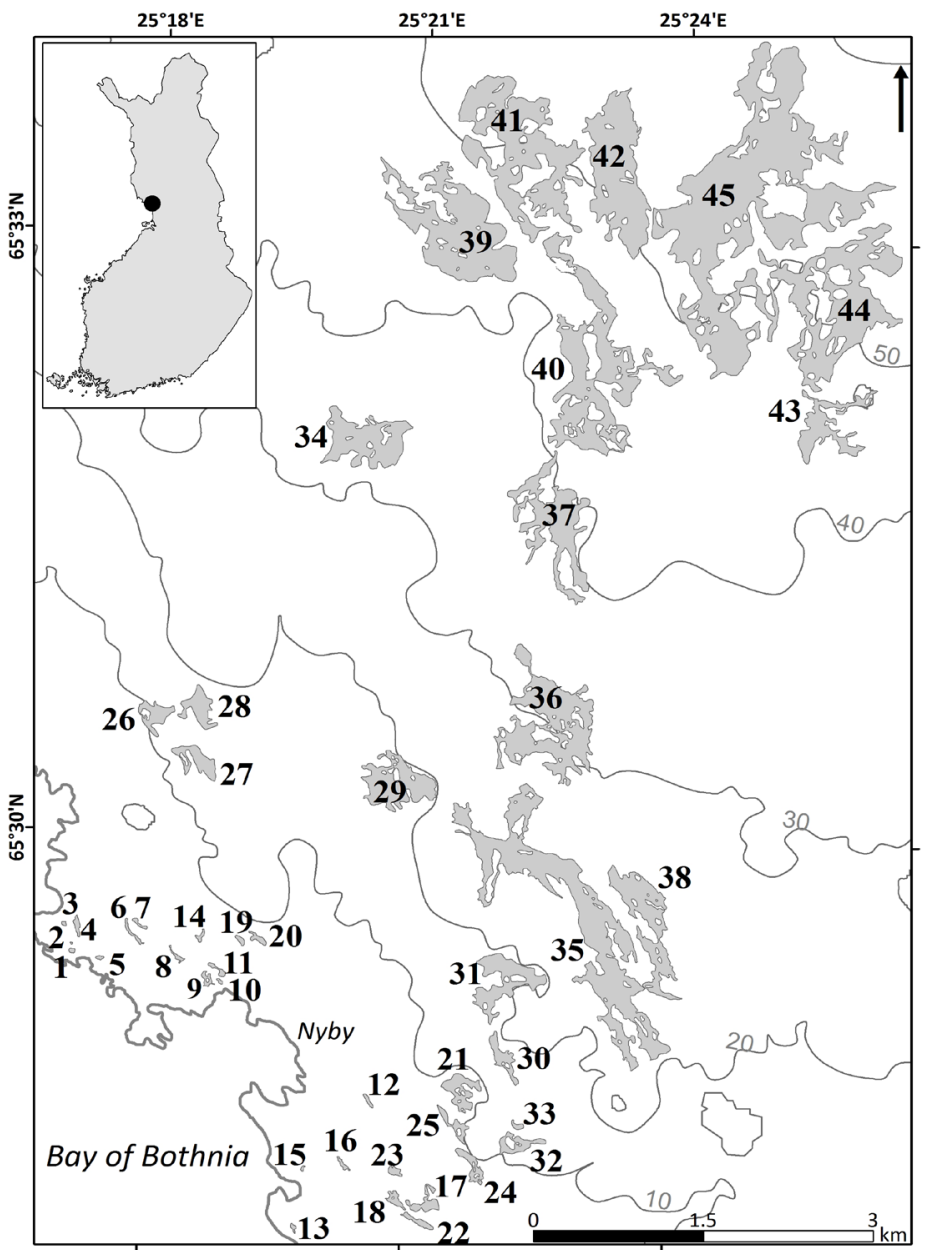

Fig. 1. The location of study area in Finland and studied wetlands, which are indicated with grey on the map: 1-4 Majava; 5-8 and 14 Ruonalampi; 9-11 Ruukinlahti; 12 Kellarioja; 13 Korkiansalmi; 15 Lastenkallio; 16 Ruonajärvi; 17 18 Ämmäjärvi; 19-20 Pikkuniitty; 21 northwest of Mustikkakangas; 22 Ämmäjärvi-Hevosjärvi; 23 northwest of Ämmäjärvi; 24 Lapinjärvi; 25 Lapinjärvi-Mustikkakangas; 26-28 Hoikkalampi-Koiralampi; 29 Soidinräme; 30 west of Sulajärvi; 31 Parviaisenkangas; 32-33 southeast of Mustikkakangas; 34 Jäkäläsuo; 35 Ulkusuo; 36 Honkisuo; 37 Käärmesuo; 38 east of Ulkusuo; 39 Antinaapa; 40 Antinjärvenaapa-Pahasuo; 41 west of Lakkasuo; 42 Lakkasuo; 43 Lamminniitty; 44 Tukalasuo; and 45 Mustanlammenaapa. Contour lines are at the intervals of $10 \mathrm{~m}$. 
We selected 45 study localities from about 70 pristine or nearly pristine wetlands of the study area for a vegetation survey in order to investigate a large number of wetlands in a short time (see Locky et al. 2005). Map contour lines were used for selecting belts with 5 and 13 localities representing altitudes $0-2.5,2.5-5,5-10,10-20,20-$ 40 and $40-60 \mathrm{~m}$ a.s.l. The sampled belts represented smaller altitude ranges at lower altitudes following the result of Brandt (1948) with narrower belts nearer the seaside. The largest mires for each belt and the variation from mires representing locations in the central parts of catchment areas and at the catchment divides were included.

We listed the vegetation types a priori (Eurola et al. 1995) for each wetland using a limited time. About one day was used for the field survey of large mire complexes, and a shorter time was used for small mires near the coast. To achieve a list representative enough for each wetland, the route of walking was chosen across various topographic units of mires visible on air photos (Laitinen et al. 2005, 2007). Observed communities were assigned to vegetation types in the field, no vegetation survey plots were used for community-to-type assignments (cf. Oliver et al. 2013). For minimizing subjective variability in the assignments, all the study localities were surveyed by the same author. In the Sphagnum fuscum bog -case, some assignments were based on air photo interpretation. Observed minimum surface areas varied considerably according to typical surface areas described for mire site types (Ruuhijärvi 1960; Eurola 1962), with the smallest observed areas ranging from 1 to $100 \mathrm{~m}^{2}$ (micro sites), mostly constituting areas larger than $100 \mathrm{~m}^{2}$ (even several hectares etc.). Communities of different spatial scales (GonzálesMegías et al. 2007) were included and analyzed jointly in order to stress the overall variation between wetlands, rather than to analyze the major variation based on large vegetation patterns only. The field survey was made 25.8.-1.10.2012.

\section{Material and basic concepts}

\section{Peatland vegetation types}

The ecologically detailed Finnish mire site type classification (Ruuhijärvi 1960; Eurola 1962; Eurola \& Kaakinen 1978; Ruuhijärvi 1983; Eurola et al. 1984, 1995, 2015; Laine \& Vasander 2005), which is a national vegetation classification for peatlands, was briefly analyzed by Pakarinen (1976) as well as Pakarinen and Ruuhijärvi (1978), and its history and current usage trends were critically discussed by Lindholm (2013b). In the present survey we use Finnish mire vegetation types as a data for a case study of 45 boreal mires of various sizes ( 0.1 to 185 ha) occupying altitudes from 1 to $53 \mathrm{~m}$ a.s.l. on a boreal land uplift coast, and interpret ecological differences between wetlands on the basis of the vegetation type data of each wetland. Six main mire vegetation units and the vegetation types in the Finnish typology are thought to form fixed points in a network of three major gradients (poorrich, mire margin to expanse, mire surface level). In the present study, the type lists recorded in the field for each wetland were used to compare the studied wetlands in relation to those major gradients. Established type abbreviations and the types of Eurola et al. (1995) were used, while the English descriptions are in Eurola et al. (1984) (cf. Ruuhijärvi 1983; Heikkilä et al. 2001).

The poor-rich gradient (Rydin et al. 1999a) as used in the present study corresponds to the trophic gradient of Eurola et al. (1984, 1995, 2015) as follows: extremely poor (fen) corresponds to oligotrophic, moderately poor (fen) to mesotrophic, intermediate (fen) to meso-eutrophic and rich (fen) to eutrophic. Six main mire vegetation units in the Finnish typology (Eurola \& Kaakinen 1978; Eurola et al. 1984, 1995, 2015) represent a specification for the mire margin to expanse gradient of Sjörs (1948): spruce mires (Bruchmoore, Ruuhijärvi 1960; Eurola 1962), swamps (Sumpfmoore, Brandt 1948) and spring vegetation (spring fens, springs) represent mire margin vegetation, and treeless poor to intermediate fens including treeless lawn and flark level bogs (Weissmoore, Ruuhijärvi 1960; Eurola 1962), rich fens (Braunmoore, Ruuhijärvi 1960; Eurola 1962) and hummock-level pine mires (Reisermoore, Ruuhijärvi 1960; Eurola 1962) represent mire expanse vegetation. Treed fens are viewed as combination site types. Spruce mire influence (Eurola et al. 1984, 1995, 2015) (Bruchmoorigkeit, Ruuhijärvi 1960; Eurola 1962) refers to a species composition of mire margin vegetation partly transitional to boreal mesic heath forests (Picea abies, Carex globularis, Equisetum sylvaticum. Sphagnum girgensohnii etc.) or herb-rich forests. Swampy vegetation features (Eurola et al. 1984, 1995, 2015) (Sumpfigkeit, Ruuhijärvi 1960) refer to treeless or treed (Betula pubescens, Alnus sp., 
Salix sp.) wetlands with species typical of shore habitats (Equisetum fluviatile, Potentilla palustris, Lysimachia thyrsiflora, Calliergon cordifolium, Sphagnum squarrosum, S. riparium etc.) (Eurola \& Kaakinen 1978; Eurola et al. 1984, 1995, 2015). Vegetation features of springs and spring fens form the third form of mire margin vegetation indicating groundwater influence (Eurola et al. 1984, 1995, 2015) (Quelligkeit, Ruuhijärvi 1960). Mire expanse vegetation is characterized by the lack of mire margin species of aforementioned three species groups. The third major mire vegetation gradient is the gradient along mires surface levels reflecting mean water table levels (Laitinen et al. 2008a). A division into a hummock level, an intermediate mire surface level (lawn) and a flark level (carpet and mud bottom) is used in Finland.

We supplemented the list of vegetation units for the analysis data on three ecological/ successional grounds. Firstly, the group of Sphagnum compactum fens (cf. Ruuhijärvi 1960; Eurola et al. 1995) (OlScomN, MeScomN, OlScomNR, MeScomNR) was regarded as separate from corresponding Sphagnum papillosum fens (OlKaN, MeKaN, OlKaNR, MeKaNR), because the former represent vegetation with unstable water regimes, while the latter represent vegetation with stable water regimes (Havas 1961; Kaakinen et al. 2008; Laitinen et al. 2008a, 2008b). On the same grounds, rare mud bottom flark fens dominated by Rhynchospora fusca (MeRhyfusRuRiN, MeRhyfusRuRiLN) were handled separate from the rest of mud bottom flark fens (Laitinen et al. 2008a). Secondly, micro sites (from 1 to $100 \mathrm{~m}^{2}$ ) of intermediate fens, rich fens and spring fens were included in the analysis in order to stress the overall vegetation variation rather than hold to a group of communities with large surface areas only: intermediate Loeskypnum badium fen (LoebadLN) (Drepanocladus badius Braunmoor Weissmoor, Ruuhijärvi 1960, meso-eutrophic Bryales fen, Eurola et al. 1995), rich Campylium stellatum fen (CaL), rich Scorpidium revolvens flark fen (RevRiL) and Warnstorfia sarmentosa spring fen (WarnsarmLäN) (mesotrophic spring fen, Eurola et al. 1995). The latter represents a poorly documented micro site occurring in the starting points of narrow soaks with sparsely growing Carex rostrata and Eriophorum angustifolium occurring as dominants in the field layer and with the bottom layer being characterized by Warnstorfia sarmentosa with mud bottom (cf. Laitinen et al. 2011). Thirdly, five local communities from low altitudes (2 to $10 \mathrm{~m}$ a.s.l.) were included in the analysis, because the Finnish mire site type classification does not specifically describe the unestablished plant communities of the land uplift coast. Extremely poor swampy tall sedge fen (OlLuSN) was a Carex rostrata-Carex aquatilis-Sphagnum riparium community in small depressions in the seaside birch forests. Alnus incana swamp (HaLu) (Kaakinen et al. 2008) is a poorly documented local community at the coast of the Bothnian Bay. Minerotrophic Sphagnum fuscum mires (MiRaR) were small-sized communities with scattered minerotrophic species (e.g. Eriohorum angustifolium) on a uniform Sphagnum fuscum surface with a discontinuous dwarf-scrub cover (see Elveland 1976). Swampy sedge fen with flark character (LuRiSN) was a local community in a young mire (17, Fig. 1) with flark species (Carex chordorrhica, Carex limosa, Menyanthes trifoliata) dominating in the field layer but with a uniform Sphagnum layer with species indicating surface water influence as dominants (Sphagnum flexuosum or Sphagnum obtusum and Sphagnum ripari$u m$ ). Moderately poor swampy sedge fen with flark character (MeLuRiSN) was a local community in a developing young aapa mire central basin (21, Fig. 1) with an Equisetum fluviatile-Carex chordorrhiza-Menyanthes trifoliata-Utricularia intermediaWarnstorfia procera-Cinclidium subrotundum stand. At higher altitudes the rich pine fen (LR) in mire 35 (22 $\mathrm{m}$ a.s.I.) represented an unusual community with a Carex lasiocarpa-Equisetum fluviatile-Carex chordorrhiza-Tomentypnum nitens stand with Sphagnum papillosum hummocks. We additionally treated Phragmites australis stands as marshes according to Keddy (2000) (cf. Brandt 1948; Eurola et al. 1995) in order to make a delicate difference between treeless swamps resembling thin-peated mires and treeless marshes more resembling mineral wetlands. One small Phragmites australis stand was further away from the seaside ( $4 \mathrm{~m}$ a.s.l.), and had an evident peat layer. The distinction of marshes from swamps was supported by the ordination.

\section{Climatic distribution features for vegetation types}

We applied three scales for the discussion about the climatic distribution patterns of vegetation types related to successional altitudes, including a global scale, a scale across nemoral (temperate) and boreal zones, and a pattern on a minor scale 
across boreal subzones. For a global scale, the ecoclimatic peatland model of Eurola \& Kaakinen (1979) provides a tool for scrutinizing the distributions of Finnish main mire vegetation units globally. Major Fennoscandian distribution of various vegetation across nemoral vs. boreal vegetation zones are visible in Scandinavia (Moen 1999; Rydin et al. 1999a), while the Finnish distributions of single (national) vegetation types show patterns on a minor scale across boreal subzones (hemiboreal, south-boreal, mid-boreal, north-boreal). Current distributional focuses of the national vegetation types were recently specified in order to evaluate their state of being threatened (Kaakinen et al. 2008); present distributions still weakly reflect climatic patterns in spite of the selective cutting down of the habitats (vegetation types) caused by man.

\section{Peatland forms}

The successional stage of the central basins of aapa mires was roughly evaluated on the basis of morphologic features. The morphologic pattern of mire complexes was interpreted from air photos (not shown), and the major morphologic units of aapa mires according to Laitinen et al. (2007) were used.

\section{Peatland locations in catchment areas}

The concepts of peripheral vs. central parts of catchment areas were used to compare the locations of wetlands in relation to landscape-level water-flow conditions. The periphery refers to catchment divides but additionally to areas near it, while the center refers to areas where the waters in the landscape tend to gather. It is question of relative altitudes between close by bedrock basins rather than of precise boundaries of actual catchment areas of different ranks. Accordingly we showed the relative altitudes of close by wetlands (centers vs. peripheries of catchment areas) with maps having contours using no boundaries of catchment areas, which are highly complicated in the area near the coast.

\section{Peatland surface areas and altitudes}

Surface areas (hectares) and altitudes ( $\mathrm{m}$ a.s.l.) of wetlands were determined for grouping wetlands on topographic grounds. Study localities were demarcated on aerial photographs along the limits of mires and mineral soil areas by using topographi- cal maps as the aid for air photo interpretation. When mires formed connected networks, the mire complexes were demarcated by cutting them from the narrowest possible sites, also roads and limits of ditched areas were used. Small ditched parts situated between pristine mire parts were included only exceptionally. Small parts of brook sides in demarcated areas were not visited. In locality 39, the northern main part was taken with. In locality 26 , the survey included the north-western half of the mire complex.

ArcMap 10.2.1 software was used for digitizing the studied mires to get precise surface areas of the mires. Digital elevation model (DEM) with a resolution of $2 \times 2$ meters and an accuracy of 0.3 meters was used for getting the mean altitude of the mires (m a.s.I.) (NLS 2010).

\section{Methods}

\section{Vegetational classification and ordination of wetlands}

To show the major ecologic pattern across the group of wetlands of Nyby and the distribution pattern of vegetation types in a compressed form on topographic map, the wetlands with a presentabsent vegetation type data were grouped into Major Vegetational Wetland Groups (MVWGs) with cluster analysis. Dissimilarities among wetlands were assessed using Raup-Crick index (Chase et al. 2011; Legendre \& Legendre 2012). This is a probabilistic index that can be used for analyzing co-occurrences among items of different frequencies. Average linkage method was used in the cluster analysis of dissimilarities (Legendre \& Legendre 2012). The data were ordinated with non-metric multidimensional scaling (NMDS) that is a robust method that can handle probabilistic measures like the Raup-Crick index (Minchin 1987). The ordination diagrams were interpreted fitting direction vectors and smooth nonlinear response surfaces. All statistical analyses were performed in the $R$ statistical environment ( $R$ Core Team 2014), and vegan package ( $R$ Core Team 2014) for multivariate analysis.

\section{Topographic classification of wetlands}

To introduce the successional patterns for the discussion section, we formed two Major Topograph- 
ic Wetland Groups (MTWGs) on the basis of the wetland size, and a set of Local Wetland Types (LWTs) on the basis of the wetland size, vegetation type composition and peatland morphology. Wetlands close to each other were called Local Wetland Groups (LGWs). The following abbreviations for wetland groups are used in this article: LWGs = Local Wetland Groups (A-E), MVWGs = Major Vegetational Wetland Groups (1-3), MTWGs = Major Topographic Wetland Groups (I-II) and LWTs $=$ Local Wetland Types (1-10).

\section{Results}

\section{Ecological pattern}

Three Major Wegetational Wetland Groups (MVWGs) (Fig. 2, 3, 4), (1) marshy mineral wetland vegetation, (2) swampy mire vegetation and (3) mire expanse vegetation, formed with cluster analysis on the basis of the vegetation type composition of the wetlands, introduced the major ecological pattern across the group of studied wetlands (Fig. 5). The first group represents wetlands with marshy (Phragmites australis) vegetation in partly littoral zones near the seaside level. The second group represents mires with partly swampy mire vegetation at least in the central parts of the mire, and the third group represents mires with mire expanse vegetation prevailing and with only sporadically having swampy mire vegetation, before all swampy Betula pubescens fen (LuNK). Sedge herb swamp (SRhLu) and Betula pubescens swamp (KoLu) confined to wetlands in MVWG 2, while vegetation types confining to wetland group 3 (mire expanse vegetation) were numerous including Carex globularis pine mire (PsR), dwarf shrub pine bog (IR), moderately poor Sphagnum papillosum tall-sedge fen (MeKaSN), extremely poor mud bottom flark fen (OIRuRiN) and practically all the rich and intermediate fen types present in Nyby.

Interpreted with the vegetation type composition of the MVWGs and with the locations of them in the ordination, the major gradient in the material appeared in the transition from MVWG 2 to 3, and represented the mire margin to expanse gradient with a diminishing of swampy vegetation features and an increase in mire expanse vegetation features. Group 1 with marshy vegetation near the seaside seemed to be the most separate group in relation to other groups according to the ordination (Fig. 6).

Major Vegetational Wetland Groups (MVWGs) broadly related to the altitude gradient (Fig. 6), while some wetlands of MVWG 3 (mire expanse

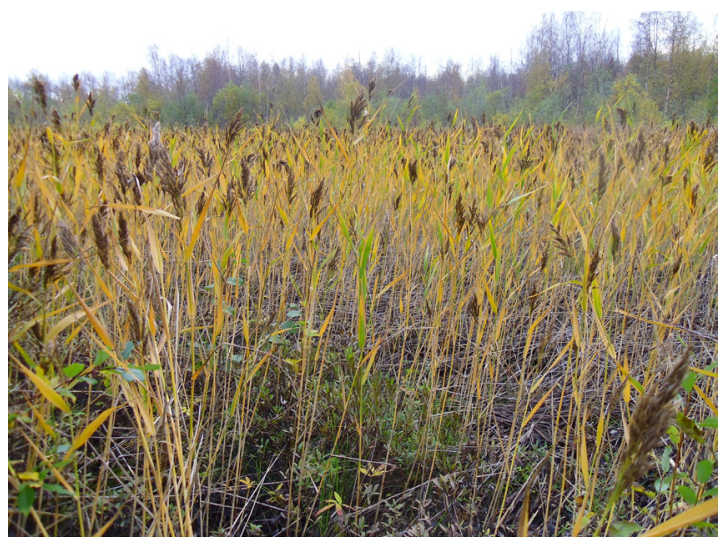

Fig. 2. Wetland 4 at Majava close to the sea at $0.8 \mathrm{~m}$ a.s.l. The locality represents wetlands with marshy mineral wetland vegetation (MVWG 1): Phragmites australis dominates, and also small amounts of Myrica gale occur. Topographically the wetland represents small reed marshes (LWT 1) within the major group small wetlands of Nyby (MTWG I). The surroundings are seaside birch forests, partly seaside Salix thickets.

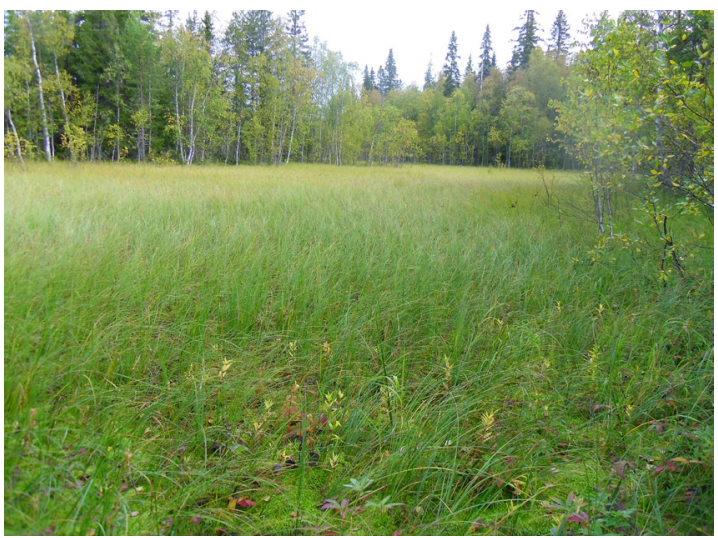

Fig. 3. Wetland 9 at Ruukinlahti at $2 \mathrm{~m}$ a.s.l. The locality represents wetlands with swampy mire vegetation (MVWG 2): Potentilla palustris, Lysimachia thyrsiflora and Sphagnum riparium indicate surface water influence (Sumpfigkeit). Topographically the wetland represents small tall sedge mires (LWT 2) within the major group small wetlands of Nyby (MTWG I). The surroundings are transitional areas from seaside birch forests to conifer forests. 


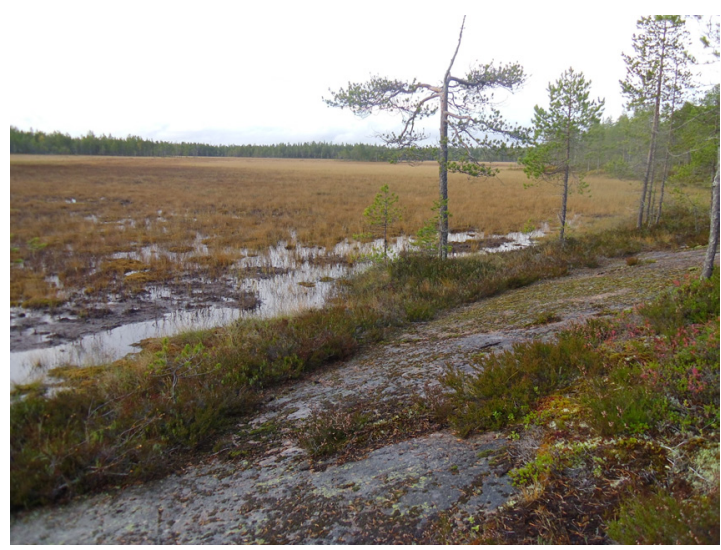

Fig. 4. Käärmesuo mire, locality 37 in the inland at $39 \mathrm{~m}$ a.s.I., bordering on rock outcrops. The locality represents wetlands with mire expanse vegetation (MVWG 3): species indicating surface water influence (Sumpfigkeit) are lacking and there occur species of wet fens (flark fens). Topographically the wetland belongs to semi-patterned aapa mires (LWT 8) within the major group evolving mire complexes of Nyby (MTWG II). Aapa-mire strings are hardly visible in the field, but in air photos of larger scales, a weak flark-string pattern is visible in large parts of the mire complex.

vegetation) also occurred at relatively low altitudes quite close to the seaside (Fig. 7). Secondly the sizes of wetlands in MVWG 3 highly varied (Fig. 7).

In the peninsula northwest of Nyby site (LWG A, Fig. 7, 8), wetlands in MVWGs 1-3 formed altitudinal belts in a relatively steep slope (threshold site) in the bedrock topography (Fig. 9, profile 1). In the peninsula south of Nyby site (LWG B, Fig. 7, 8 ) wetlands in MVWGs 2 and 3 occurred mixed with no belts from the seaside to the inland. Among nearby wetlands, wetlands in MVWG 2 (swampy mire vegetation) occurred at altitudes lower than those in MVWG 3 (mire expanse vegetation). Irregularly rugged bedrock topography (Fig. 9, profile 2) prevailed in that area. At higher altitudes (LWGs C-E) mires mainly belonged to MVWG 3.

\section{Topographic pattern}

Small wetlands (I, Table 1) $(0.1-1 \mathrm{ha}, 1-10 \mathrm{~m}$ a.s.I.) had four Local Wetlands Types (LWTs). (1) Small reed marshes (0.1-0.7 ha) (Table 2, Fig. 8) did not belong to mires proper in having no peat layer and no mire vegetation. The centers of wetlands were occupied by Phragmites marsh (RuLu) with scattered patches of Sphagnum squarrosum. In the peripheries of the depressions, Salix Myrica swamp (PaMyrLu) was found in some cases. The surroundings were partly Salix phylicifolia thickets, mostly coastal birch forests. (2) Small tallsedge mires (0.1-0.7 ha) (Tables 2 and 3, Fig. 7) occurred in small depressions in seaside birch forests or near them. Three mires (Fig. 6, mires 6, 8, 10) were solely composed of swamp types including the sedge herb swamp (RuLu) and the Betula pubescens swamp $(\mathrm{KoLu})$, while in the other mires swampy fen vegetation with monotonous tallsedge stands (Carex rostrata, C. aquatilis) and uniform Sphagnum cover (often S. riparium) dominated. (3) Small Sphagnum mires (0.1-1 ha) (Table 2, 3, Fig. 7) were either characterized by extremely poor Sphagnum flark fen (OlSphRiN) or extremely poor short-sedge pine fen (OlLkR). (4) Small pine and spruce mires (0.4-0.7 ha) (Table 2, Fig. 7) were characterized by Carex globularis pine mire dominated by Sphagnum fuscum (PsR), other pine mires (RaR, IR, PsKR), swampy Betula pubescens fen (LuNK) and thin-peated Vaccinium myrtillus spruce mire (MKgK).

Evolving mire complexes (II, Table 1) (2-185 ha, 4-53 m a.s.l.) had six LWTs (5-10). (5) Unpatterned swampy aapa mires (2-14 ha) (Tables $4,3,5$, Fig. 7) were mainly relatively small mires and had central basins with at least partly swampy vegetation, while peripheral parts were variably developed and could have extremely poor lawn fen types (OILkR, OIKaN with Eriophorum vaginatum) (Table 4, mire 21). (6) Unpatterned lawn aapa mires of Nyby (4-6 ha) (Table 4, 5, Fig. 7) were relatively small sloping mires at low altitudes (10-17 $\mathrm{m}$ a.s.l.) near catchment divides. They had extremely poor lawn fen types (OlLkN, OIKaN, OIKaNR with Trichophorum cespitosum, OILkR). Central basins were small and poorly discernible on air photos. (7) Unpatterned flark aapa mires (19-82 ha) (Table 5, Fig. 7) at the altitude from 18 to $22 \mathrm{~m}$ a.s.l. were characterized by central basins with considerable areas with moderately poor mud bottom flark fen (MeRuRiN) dominated by Carex livida. Such flark fens also occurred abundantly in patterned aapa mires at higher altitudes. In the peripheral parts of unpatterned flark aapa mires there also occasionally occurred moderately poor fen (Me-) types (MeKaSR, MeKaSN), which were absent from small unpatterned lawn aapa 

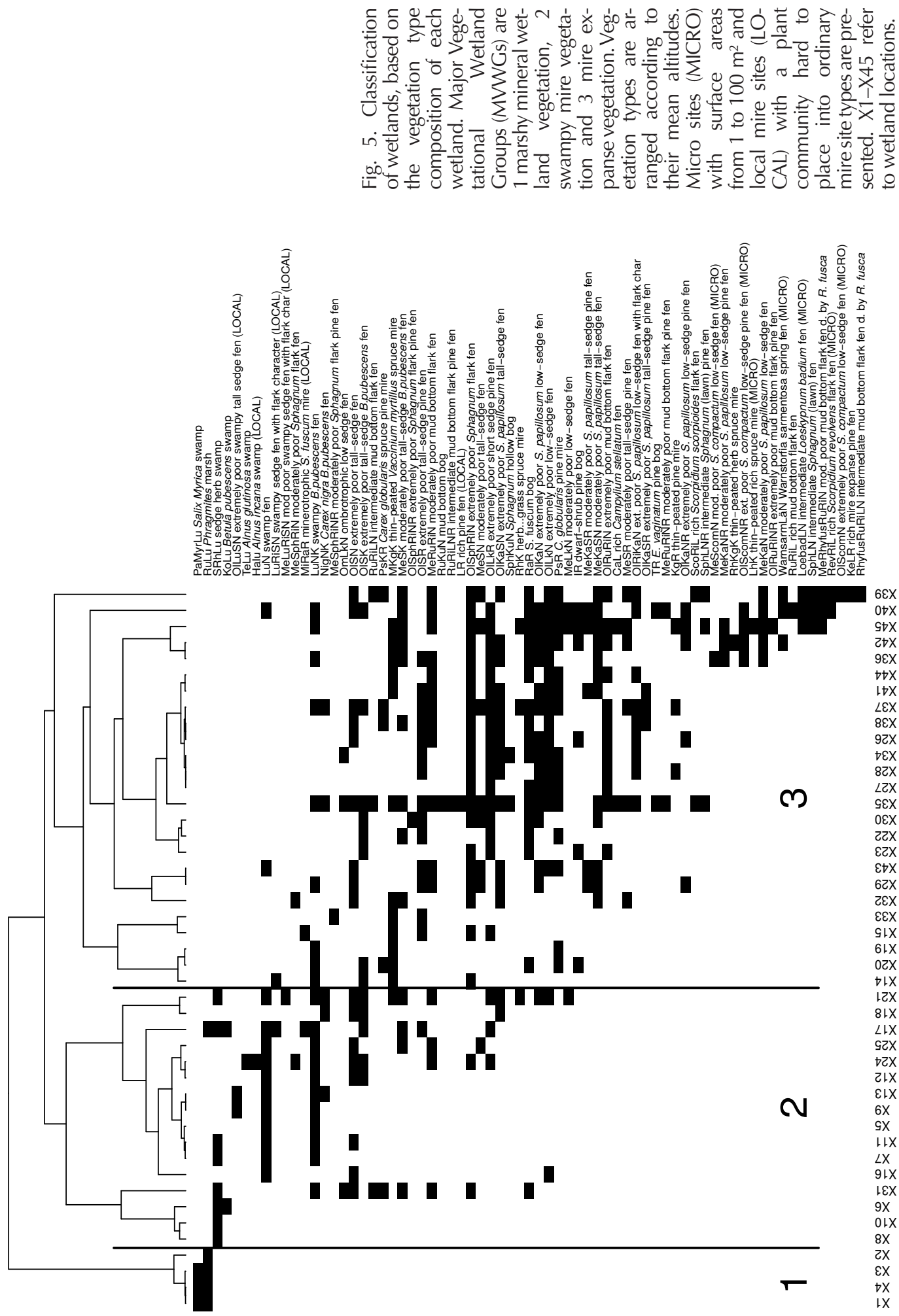
mires at lower altitudes. Large unpatterned flark aapa mire 35 (Ulkusuo) had a high number of vegetation types including intermediate (SphLNR) and rich fen types (CaL, ScoRiL). Several areas of Sphagnum fuscum bog occurred. (8) Semi-patterned aapa mires (22-31 ha) (Table 5, 6, Fig. 7) were characterized by weakly discernible strings at least in small parts of their central basins. (9) Aapa Sphagnum fuscum bog 34 (Jäkäläsuo) (24 ha) (Table 6, Fig. 7) was dominated by a bog part, which was unpatterned and nearly treeless, but additionally had a minor aapa mire part with a flark-dominated central basin (with a poorly developed flark-string pattern) and a narrow lawn-dominated peripheral part. (10) Patterned aapa mires (14-185 ha) (Table 5, 6, Fig. 7) had clearly discernible strings at least in small parts of their central basins. Proportions of flark-level dominated central basins, lawndominated peripheral parts and small Sphagnum fuscum bogs varied among mires. The distal parts of two mire complexes (number 41 and 42) had outlet fens (Laitinen et al. 2007) with a highly dense flark-string pattern. The locality at the lowest altitude (30 $\mathrm{m}$ a.s.I.), which was ascribed to patterned aapa mires (Honkisuo, mire 36), was specified by the occurrence of broad Molinia caerulea strings clearly visible on air photos.

Among both MTWGs, LWTs with marshy or at least partly swampy vegetation (LWTs 1, 2, 5) mainly located in the central parts of catchment areas (Table 1). LWTs among small mires with mainly mire expanse vegetation (LWTs 3, 4) located in the peripheral parts of catchment areas. LWTs among aapa mires with mainly mire expanse vegetation (LWTs 6-10) had variation with regard to the location of mires in catchment areas.

\section{Distribution of vegetation types across topographic groups}

Two thirds of frequent vegetation types were common to small wetlands and evolving mire complexes (Table 7), while only one fifth of infrequent communities and vegetation types were common to two MTWGs (Table 8). Vegetation types common to small wetlands and aapa mires occurred across the whole range of altitudinal variation present, from about 1 to $53 \mathrm{~m}$ a.s.l. (Table 7, 8), while only two communities (Salix Myrica swamp, PaMyrLu, and extremely poor swampy tall-sedge fen, OlLuSN) were present in small wetlands but not in mire complexes (Table 8). Vegetation types present only in evolving mire complexes occurred at the altitude from about 6 to $53 \mathrm{~m}$ a.s.l, and their bulk occurred from 11 to $53 \mathrm{~m}$ a.s.l, where wetlands belonging to small wetlands were absent in the present material. Moderately poor fen (Me-) types with mire expanse vegetation did not occur until at evolving mire complexes, and among them they
Fig. 6. Ordination of wetlands and contours (m a.s.l.) as mean values. Major Vegetational Wetland Groups (MVWGs) are 1 marshy mineral wetland vegetation, 2 swampy mire vegetation and 3 mire expanse vegetation. The locality numbers of wetlands are in boxes.

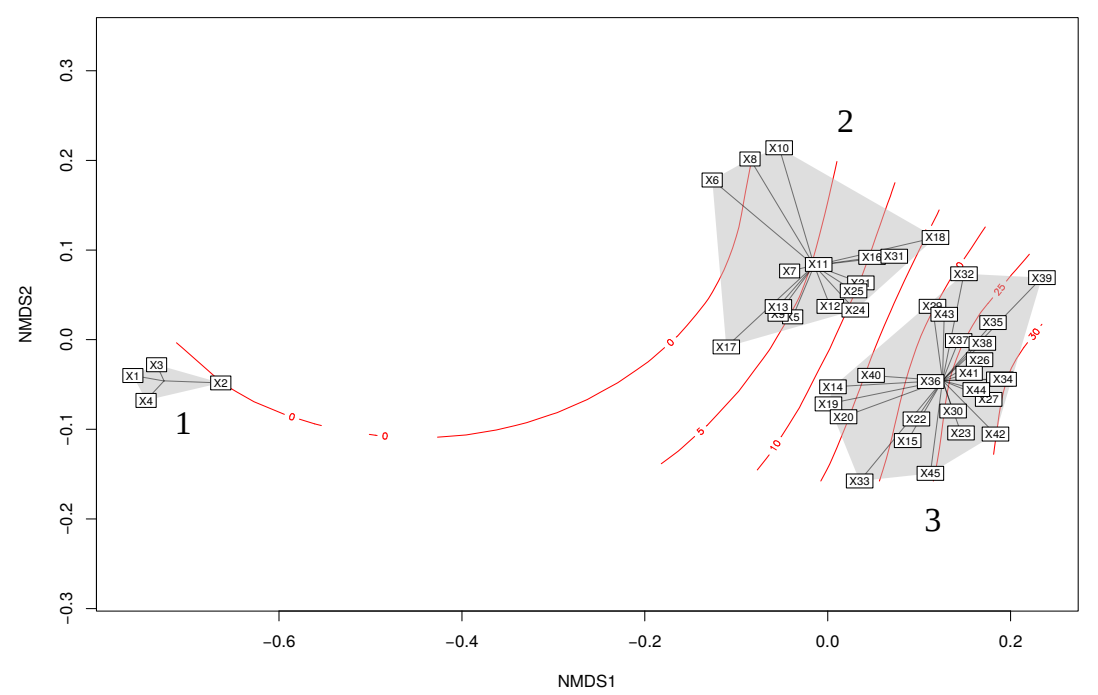




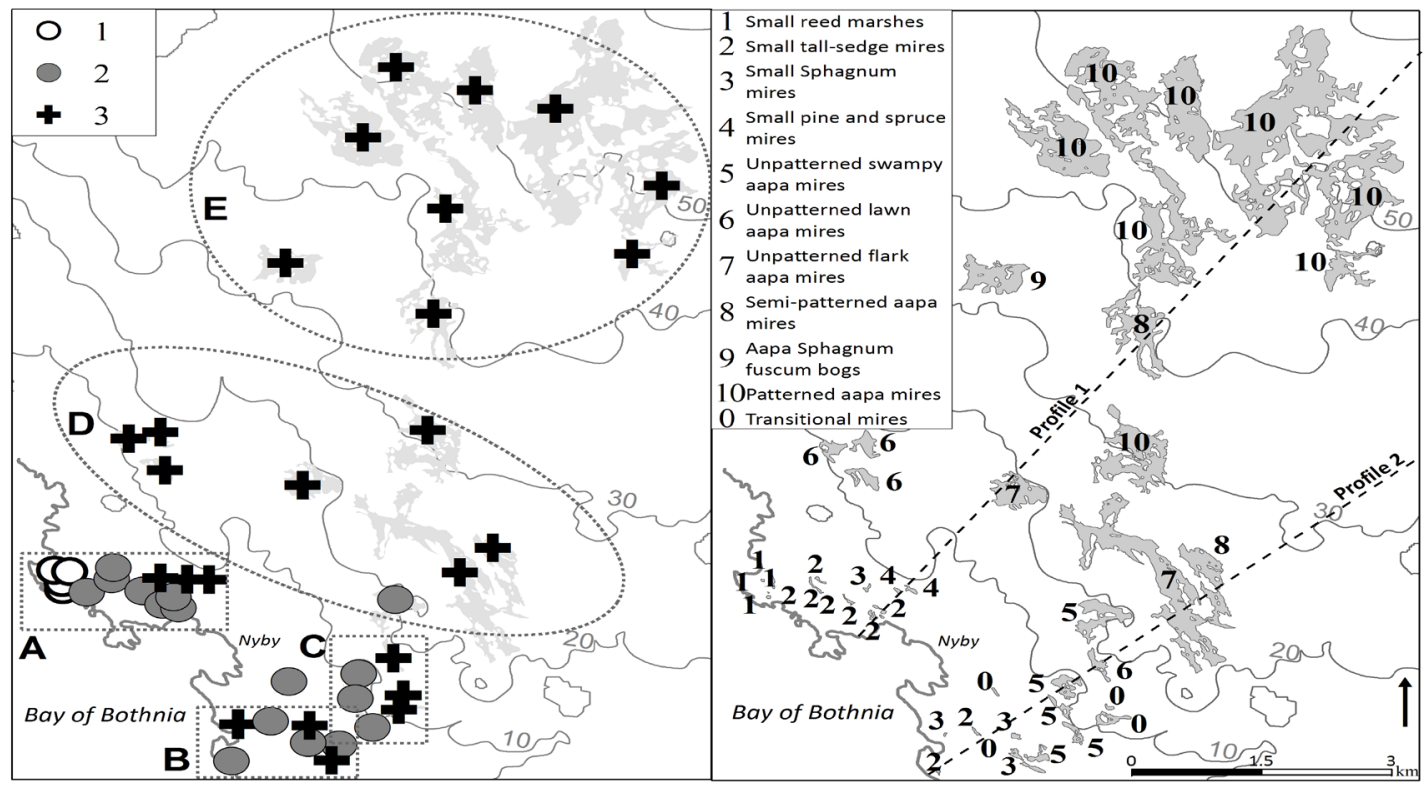

Fig. 7. Major Vegetational Wetland Groups (MVWGs: 1 marshy mineral wetland vegetation, 2 swampy mire vegetation, 3 mire expanse vegetation) and local wetland groups (LWGs A-E) in the map on the left. Local wetland types (LWTs 1-10, where transitional mires (0) refer to wetlands not classified on the level of local wetland types) and the locations of two altitude profiles (Fig. 9) in the map on the right. Contour lines are at the intervals of $10 \mathrm{~m}$.

did not occur at the lowest altitudes. The most frequent vegetation type of this group was moderately poor Sphagnum papillosum tall-sedge fen (MeKaSN) (Table 7).

Among frequent vegetation types (Table 7), swampy birch fen (LuNK) had a wide range across local wetland types both within small wetlands and mire complexes. Extremely poor Sphagnum flark fen (OlSphRiN) characterized small Sphagnum mires (4-6 $\mathrm{m}$ a.s.l.) among small wetlands and showed the highest frequency of all the vegetation types across the whole set of evolving mire complexes. Extremely poor short sedge pine fen (OlLkR) showed the same pattern. Sphagnum fuscum bog (RaR) occurred among small wetlands from small Sphagnum mires (4-6 m a.s.l.) to small pine and spruce mires (7-9 $\mathrm{m}$ a.s.l.). The occurrence of Sphagnum fuscum bog (RaR) in mire complexes strikingly resembled its occurrence in small wetlands: it was most frequent at relatively high altitudes in both groups, while it occurred across the whole set of mire complexes. The pattern of Carex globularis pine mire (PsR) resembled that of the Sphagnum fuscum bog.
Among infrequent vegetation types (Table 8), Salix Myrica swamp (PaMyrLu) confined to the peripheral parts of reed marshes (LWT 1). Betula pubescens swamp (KoLu) occurred both in small wetlands and aapa mires but confined to swampy local types, to small tall-sedge mires (0.7-3 m a.s.l.) and to unpatterned swampy aapa mires (4-18 m a.s.l.). Rare Alnus glutinosa swamp (TeLu) and rare Alnus incana swamp (HaLu) confined here to the unpatterned swampy aapa mire 24 (Fig. 1), but the findings, however, did not represent totally intact vegetation, because they were affected by the additional water flow and supplementary nutrients derived from a former, overgrown artificial ditch. Moderately poor swampy sedge fen with flark character (MeLuRiSN, incl. Cinclidium subrotundum) was a significant community confining to unpatterned swampy aapa mires (locality 21, Fig. 1). Intermediate mud bottom flark fen (MeRuRiLN) occurred scantily across almost the whole set of mire complexes. A specific group of vegetation types not present until in some of patterned aapa mires of LWG $\mathrm{E}$ at high altitudes (43-53 m a.s.I.) (Table 6) were moderately poor spring fen patches (Warn- 

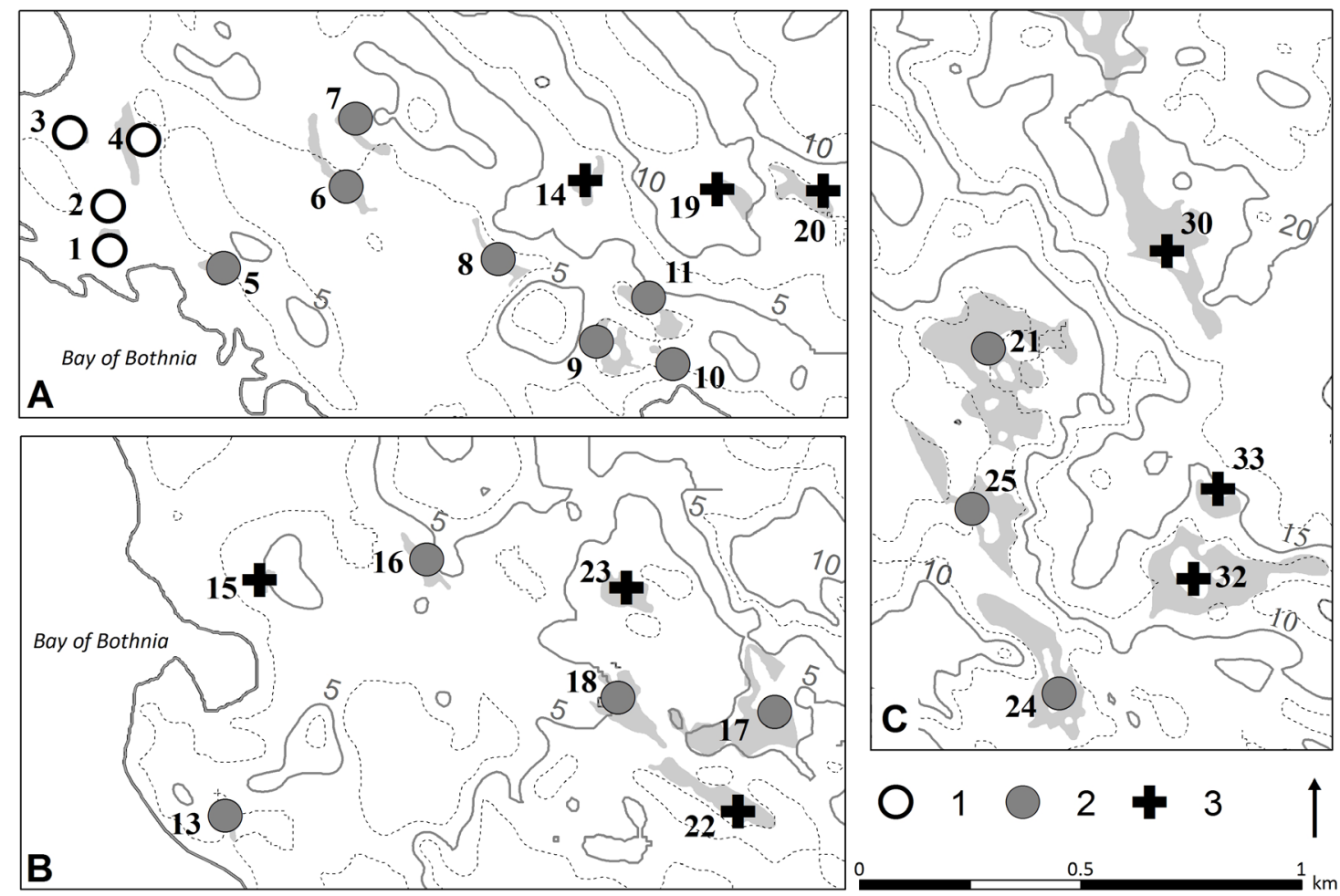

B

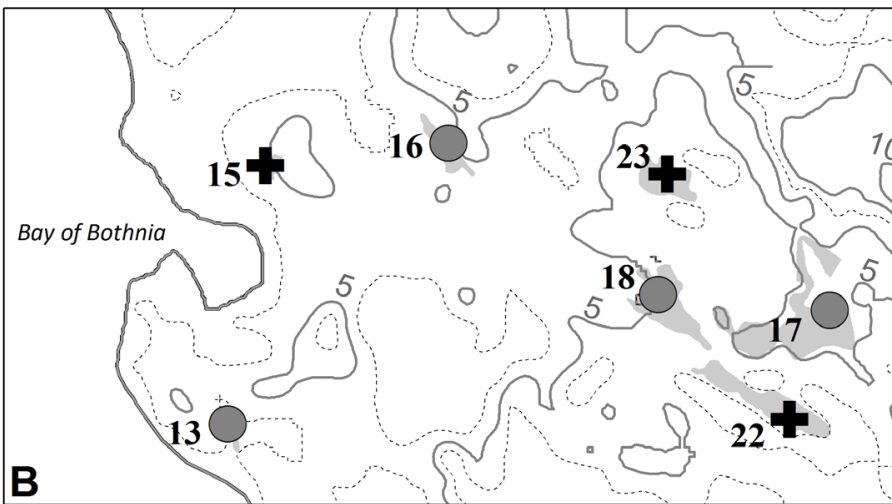

Fig. 8. Local Wetland Groups (LGWs): A wetland group (1-10 m a.s.l.) in peninsula north of Nyby site, B wetland group (2-6 $\mathrm{m}$ a.s.l.) in peninsula south of Nyby site, and C wetland group (6-18 $\mathrm{m}$ a.s.l.) in the inland near the seaside. Major Vegetation Wetland Groups (MVWGs) are 1 marshy mineral wetland vegetation, 2 swampy mire vegetation, 3 mire expanse vegetation. Contour lines are at the intervals of $5 \mathrm{~m}$. For the vegetation type compositions of wetland groups A, B and C, see Table 2, 3 and 4, respectively. For vegetation type compositions of wetland groups D and E, see Table 5 and 6, respectively, and Fig. 7.

sarmLäN), patches and small areas of intermediate Loeskypnum badium fen (LoebadLN), small areas of intermediate Sphagnum (lawn) fen (SphLN), patches or small areas of rich mud bottom flark fens (RuRiL) and rich Scorpidium revolvens flark fens (RevRiL) and moderately poor and intermediate flark fens dominated by Rhynchospora fusca (MeRhyfusRuRiN, RhyfusRuRiLN).

\section{Discussion}

\section{Use of vegetation types for analysis}

Classification and ordination approaches were used for the analysis of the wetland groups and for the interpretation of the succession in this research. However, instead of the plant species lists recorded from small sample plots of a standard size (Rehell et al. 2012a, 2012b; Tuittila et al. 2013), we used the vegetation type lists of the Finnish mire site types, recorded from whole wetlands of highly various sizes. The approach seemed to operate, as the results were reasonable. Vegetation type lists, along with species lists, are frequently used in Finland in practical projects for comparing the conservation values of localities, using official conservation status for national vegetation types (Raunio et al. 2008). Generally, the relying on vegetation types is a result of a long history in practical vegetation science in Finland (Oksanen 1990; Lindholm 2013b). Scientific research has not previously used vegetation type lists as 
data for analyses because vegetation types are subjective units compared to normally used species. In our opinion, however, this kind of usage of the vegetation types is valid for a large-scale vegetation survey intending to show only major trends between entire wetlands. Another special question for the usage of the vegetation types in the present study is the poor specification of the mire vegetation types near the coast (Brandt 1948), perhaps partly with the exception of the swamp vegetation (Eurola \& Kaakinen 1978; Eurola et al. 1984, 1995, 2015) at the lowest altitudes. This brings a possible cause for a mistake, which we tried to overcome by providing supplementary communities frequently observed in the zone above the coastal
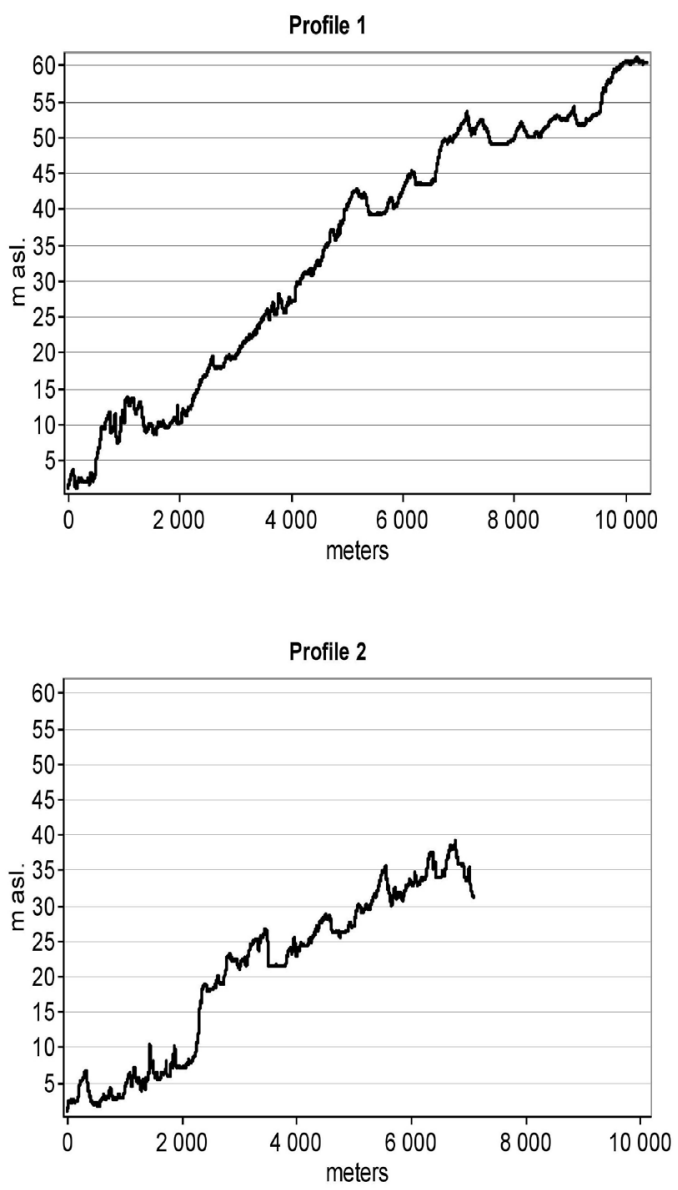

Fig. 9. Altitude relationships of the study area. The locations of the profiles 1 and 2 are indicated in Fig. 7. marshes and swamps. The additional communities, however, are only shortly described with no basic documentation with sample plots. This approach to describing plant communities is not valid from the point of view of a specific description of new plant communities but may be applied for the present study representing a survey-like geographic investigation with a limited time for the field work.

\section{Ecological and hydrological patterns across wetlands}

The major vegetation type gradient for the whole group of wetlands of Nyby was interpreted with the classification and ordination of entire wetlands on the basis of their vegetation type composition (Fig. 5, 6). After several attempts and comparisons, it appeared that a solution in clustering with no more than three MVWGs (1 reed marshes, 2 swampy mire vegetation, 3 mire expanse vegetation) is valid. The three-division into MVWGs, and the locations of each group in the ordination, highlight the major vegetation type gradient among Nyby wetlands. Reed marshes (1) seem a relatively separate group, and they represent mainly mineral wetland vegetation dominated by Phragmites australis (e.g. with Myrica gale) with an occasional surface water influence of the brackish water along with the surface water influence of the fresh water (Sumpfigkeit, Tuomikoski 1955; Ruuhijärvi 1960). The transition from MVWG 2 to 3 represents a classic mire margin to expanse gradient with the mire margin vegetation here referring to swamps (Eurola et al. 1984, 1995, 2015) and the mire expanse vegetation mainly referring to treeless poor to intermediate fens including treeless lawn and flark level bogs (Weissmoore, Ruuhijärvi 1960; Eurola 1962) and to hummock-level pine mires (Reisermoore, Ruuhijärvi 1960; Eurola 1962), and for a diminutive part to rich fens with mire expanse vegetation (Braunmoore, Ruuhijärvi 1960). The gradient from swamps to mire expanse vegetation represents a highly expected pattern, which is indirectly shown with vegetation descriptions as a major gradient from south-boreal coastal mires to raised bogs (Aario 1932; Brandt 1948) and as a gradient from mid-boreal coastal mires to aapa mires (Kukko-oja et al. 2003). In the latter study area (Siikajoki sand area), the universally much used fen to bog gradient was shown as a major succession gradient in the study of Tuittila et 
Table 1. Topographic and ecological patterns of Nyby wetlands based on the wetland classifications. The characteristic locations of wetlands on catchment areas are shown.

\begin{tabular}{|c|c|c|c|}
\hline \multicolumn{2}{|l|}{ Topographic pattern } & \multirow{2}{*}{$\begin{array}{l}\text { Ecological pattern } \\
\text { Major Vegetational Wetland } \\
\text { Groups (MVWGs) }\end{array}$} & \multirow{2}{*}{$\begin{array}{l}\text { Principal locations of } \\
\text { wetlands }\end{array}$} \\
\hline $\begin{array}{l}\text { Major Topographic } \\
\text { Wetland Groups } \\
\text { (MTWGs) }\end{array}$ & $\begin{array}{l}\text { Local Wetland Types } \\
\text { (LWTs) }\end{array}$ & & \\
\hline - wetland size & $\begin{array}{l}\text { - } \text { wetland size } \\
\text { - } \text { vegetation type } \\
\text { composition } \\
\text { - } \\
\text { peatland } \\
\text { morphology }\end{array}$ & $\begin{array}{l}\text { vegetation type } \\
\text { composition (cluster a.) }\end{array}$ & $\begin{array}{l}\text { - littoral of the sea } \\
\text { - central or peripheral part } \\
\text { of a catchment area }\end{array}$ \\
\hline \multirow[t]{3}{*}{$\begin{array}{l}\text { I Small wetlands } \\
\text { (0.1-1 ha, } 1-10 \mathrm{~m} \\
\text { a.s.l.) }\end{array}$} & $\begin{array}{l}1 \text { Small reed marshes } \\
(0.1-0.7 \text { ha, } 0.8-1.2 \mathrm{~m} \\
\text { a.s.l. })\end{array}$ & $\begin{array}{l}1 \text { Marshy mineral wetland } \\
\text { vegetation }\end{array}$ & $\begin{array}{l}\text { Littoral } \\
\text { Center }\end{array}$ \\
\hline & $\begin{array}{l}2 \text { Small tall-sedge mires } \\
\text { (0.1-0.7 ha, } 0.7-3 \mathrm{~m} \\
\text { a.s.l.) }\end{array}$ & $\begin{array}{l}2 \text { Swampy mire } \\
\text { vegetation }\end{array}$ & Center \\
\hline & $\begin{array}{l}\text { 3 Small Sphagnum } \\
\text { mires } \\
(0.1-1 \text { ha, } 4-6 \mathrm{~m} \text { a.s.l. }) \\
\mathbf{4} \text { Small pine and spruce } \\
\text { mires } \\
(0.4-0.7 \text { ha, } 7-9 \mathrm{~m} \\
\text { a.s.l. })\end{array}$ & 3 Mire expanse vegetation & Periphery \\
\hline \multirow{2}{*}{$\begin{array}{l}\text { II Evolving mire } \\
\text { complexes } \\
(2-185 \text { ha, } 4-53 \mathrm{~m} \\
\text { a.s.l.) }\end{array}$} & $\begin{array}{l}5 \text { Unpatterned swampy } \\
\text { aapa mires } \\
(2-14 \text { ha, } 4-18 \mathrm{~m} \text { a.s.l. })\end{array}$ & 2 Swampy mire vegetation & Center \\
\hline & $\begin{array}{l}6 \text { Unpatterned lawn } \\
\text { aapa mires } \\
(4-6 \text { ha, } 10-18 \mathrm{~m} \text { a.s.l.) } \\
7 \text { Unpatterned flark } \\
\text { aapa mires } \\
(9-82 \text { ha, } 18-22 \mathrm{~m} \text { a.s.l.) } \\
\text { 8 Semi-patterned aapa } \\
\text { mires } \\
(22-31 \mathrm{ha}, 25-40 \mathrm{~m} \\
\text { a.s.l.) } \\
\text { 9 Aapa Sphagnum } \\
\text { fuscum bogs } \\
(24 \text { ha, } 34 \mathrm{~m} \text { a.s.l.) } \\
\text { 10 Patterned aapa } \\
\text { mires } \\
(14-185 \text { ha, 30-53 m } \\
\text { a.s.l.) }\end{array}$ & 3 Mire expanse vegetation & $\begin{array}{l}\text { Periphery } \\
\text { Center or } \\
\text { Center-periphery } \\
\text { Center-periphery } \\
\text { Periphery } \\
\text { Center or } \\
\text { Center-periphery }\end{array}$ \\
\hline
\end{tabular}

al. (2013). This is not, however, necessarily at odds with the result of Kukko-oja et al. (2003) and with the result of the present study, because the study of Tuittila et al. (2013) holds to the ombro-minero gradient, not specifically dealing with the mire margin to expanse gradient, and because 'bog' is used in a wide and general sense avoiding the questions of specific mire complex types such as aapa mires vs. raised bogs. We conclude that the result of the present study, as far as the major vegetation gradient is concerned, contributes to a pattern already established for mires at different altitudes on the land uplift coast rather than provides new viewpoints for the gradient relationships of boreal coastal mires. From other aspects of mire margin vegetation, spruce mire influence (Bruchmoorigkeit, Ruuhijärvi 1960) occurs sporadically at different altitudes in the wetlands of Nyby, while groundwater influence (Quelligkeit, Ruuhijärvi 1960) is highly scanty. The scantiness of the spruce mires and spring fens is probably affected by the prevailing bedrock terrain, as called by Alalammi (1990).

In hydrological interpretations between the vegetation and the water-flow pattern, the entirety of mineral-soil areas, brooks, ponds, wetlands and man-made ditches etc. exactly shows the actual pattern. The present material has a constraint of 45 wetlands in this study representing a sample of wetlands (which, however, constitutes the bulk of 
Table 2. Local Wetland Group A in peninsula north of Nyby site (1-10 m a.s.I., all wetlands below one hectare). For each wetland location (see Fig. 1 for place names), Major Vegetational Wetland Group (MVWG), Major Topographic Wetland Group (MTWG), Local Wetland Type (LWT), altitude, area and vegetation types are shown. Wetlands are arranged according to vegetation type composition (1 marshy mineral wetland vegetation, 2 swampy mire vegetation, 3 mire expanse vegetation) and altitude within each major group. Vegetation types are arranged according to their mean altitude in the whole material. LWTs are 1 small reed marshes, 2 small tall-sedge mires, 3 small Sphagnum mires and 4 small pine and spruce mires. For summary of local wetland types, see Table 1. LOCAL refers to a local community.

\begin{tabular}{|c|c|c|c|c|c|c|c|c|c|c|c|c|c|c|c|c|}
\hline Wetland location & & & 1 & 4 & 3 & 2 & 8 & 10 & 6 & 7 & 11 & 5 & 9 & 14 & 20 & 19 \\
\hline MVWG & & & 1 & 1 & 1 & 1 & 2 & 2 & 2 & 2 & 2 & 2 & 2 & 3 & 3 & 3 \\
\hline MTWG & & & I & I & I & 1 & 1 & 1 & 1 & I & I & 1 & I & I & 1 & 1 \\
\hline LWT & & & 1 & 1 & 1 & 1 & 2 & 2 & 2 & 2 & 2 & 2 & 2 & 3 & 4 & 4 \\
\hline Altitude ( $\mathrm{m}$ a.s.l.) & & & 0.8 & 0.8 & 1 & 1 & 0.7 & 1 & 1 & 2 & 2 & 2 & 2 & 5 & 7 & 9 \\
\hline Area (hectares) & & & 0.2 & 0.7 & 0.1 & 0.0 & 0.4 & 0.1 & 0.6 & 0.4 & 0.6 & 0.2 & 0.7 & 0.4 & 0.7 & 0.4 \\
\hline \multicolumn{17}{|l|}{ Vegetation type } \\
\hline & PaMyrLu & Salix Myrica swamp & $x$ & $x$ & $x$ & & & & & & & & & & & \\
\hline & RuLu & Phragmites marsh & $x$ & $x$ & $x$ & $x$ & & & & & & & & & & \\
\hline & SRhLu & Sedge herb swamp & & & & & $\mathrm{X}$ & $\mathrm{X}$ & $\mathrm{X}$ & $\mathrm{X}$ & $\mathrm{X}$ & & & & & \\
\hline & KoLu & Betula pubescens swamp & & & & & & & $x$ & & & & & & & \\
\hline & OILuSN & Extremely poor swampy tall sedge fen (LOCAL) & & & & & & & & & & & $x$ & & & \\
\hline & LuN & Swamp fen & & & & & & & & $x$ & $x$ & $x$ & $x$ & & & \\
\hline & LuRiSN & Swampy sedge fen with flark character (LOCAL) & & & & & & & & & & & & $X$ & & \\
\hline & LuNK & Swampy Betula pubescens fen & & & & & & & & $x$ & $x$ & $x$ & $x$ & $x$ & $x$ & $x$ \\
\hline & OISN & Extremely poor tall-ssedge fen & & & & & & & & & $x$ & & & & & \\
\hline & OISK & Extremely poor tall-sedge Betula pubescens fen & & & & & & & & & & & & $\mathrm{X}$ & $\mathrm{X}$ & \\
\hline & PsKR & Carex globularis spurce pine mire & & & & & & & & & & & & & $x$ & \\
\hline & MKgK & Thin-peated Vaccinium myrtillus spruce mire & & & & & & & & & & & & $x$ & $x$ & $x$ \\
\hline & OlSphRiN & Extremely poor Sphagnum flark fen & & & & & & & & & & & & $\mathrm{X}$ & & \\
\hline & $\mathrm{RaR}$ & Sphagnum fuscum bog & & & & & & & & & & & & & $\mathrm{X}$ & \\
\hline & PsR & Carex globularis pine mire & & & & & & & & & & & & & $x$ & $x$ \\
\hline & IR & Dwarf-shrub pine bog & & & & & & & & & & & & & $x$ & \\
\hline
\end{tabular}

wetlands present in Nyby area). The following pattern, thus, seems evident in Nyby. The distribution of vegetation types in small wetlands $(1-10 \mathrm{~m}$ a.s.I.) in LWG B (Fig. 8) south east of Nyby site shows a pattern related to the locations of those wetlands in peripheries vs. centers of minute catchment areas. Wetlands on hills, which are in the peripheral parts of catchment areas, have mire expanse vegetation (MVWG 3), while wetlands in depressions, which are in the central parts of catchment areas, have swampy mire vegetation (MVWG 2) (Sumpfigkeit, Tuomikoski 1955; Ruuhijärvi 1960). This simple topographic pattern highly agrees with the hypothesis of Ivanov (1981) for larger mire complexes, according to which the rate of acrotelmic flow of water in the catchment centers of mires exceeds that in the catchment peripheries of those mires. We conclude that the distribution of the Major Vegetational Wetland Groups (MVWGs) among this coastal group of mires specifically responds to a hydrological pattern suggested by Ivanov (1981). There is evidence (Hose et al. 2014) that this pattern refers to a general pattern in wetlands: the vegetation structure of wetlands highly responses to even slight altitude differences (one or a couple of meters) in the landscape, and even the vegetation of separate wetlands at slightly higher altitudes deviates from that in the corresponding nearby wetlands at slightly lower altitudes. This highlights the significance of the water-flow pattern in the landscape and the necessity to consider the vegetation of mires in connection with their topographic positions and in connection with the vegetation of close by mires.

\section{Topographic and climatic distribution of vegetation types}

Vegetation types in Nyby and the Finnish main mire vegetation units (Eurola et al. 1984) have various climatic distribution features and relationships to primary succession. Swamps (as a group) with a southern global distribution (Eurola \& Kaakinen 1979) and with a Finnish distribution focus in the hemiboreal zone (Eurola et al. 1995; Kaakinen et al. 2008) concentrate on low altitudes in Nyby $($ Table 7,8$)$ as in the south-boreal 
raised bog zone of Finland (Brandt 1948). The southern character of the swamps, included with the reed marshes (Brandt 1948; Eurola et al. 1984, 1995, 2015), deserves consideration, as according to an optional mire zone and section division of North Fennoscandia (Eurola \& Vorren 1980), a narrow coastal zone around the northern end of the Gulf of Bothnia (with a part of Nyby study area) belongs to the south-boreal zone instead of the mid-boreal zone. In our opinion, however, the preference of swamps near the seaside is perhaps a successional feature rather than a climatic or vegetation-zonal feature because there is no evidence from a climatic difference between the sites near the sea and the sites at slightly higher altitudes in the lowland.

Vegetation types with a current mid-boreal focus in Finland (Kaakinen et al. 2008) mainly avoid the lowest altitudes characterized by the reed marshes and swamps in Nyby. Such vegetation

Table 3. Local Wetland Group B in peninsula south of Nyby site (2-6 m a.s.l., below 1-3 hectares). For each wetland location (see Fig. 1 for place names), Major Vegetational Wetland Group (MVWG), Major Topographic Wetland Group (MTWG), Local Wetland Type (LWT), altitude, area and vegetation types are shown. Wetlands are arranged according to vegetation type composition (2 swampy mire vegetation, 3 mire expanse vegetation), and altitude within each major group. Vegetation types are arranged according to their mean altitude in the whole material. LWTs are 0 transitional mires (not classified into LWTs), 2 small tall-sedge mires, 3 small Sphagnum mires and 5 unpatterned swampy aapa mires. For summary of LWTs, see Table 1. LOCAL refers to a local community.

\begin{tabular}{|c|c|c|c|c|c|c|c|c|c|}
\hline Wetland location & & & 13 & 16 & 17 & 18 & 15 & 22 & 23 \\
\hline MVWG & & & 2 & 2 & 2 & 2 & 3 & 3 & 3 \\
\hline MTWG & & & I & I & $\|$ & I & I & I & 1 \\
\hline LWT & & & 2 & 2 & 5 & 0 & 3 & 3 & 3 \\
\hline Altitude (m a.s.I.) & & & 2 & 3 & 4 & 5 & 4 & 6 & 6 \\
\hline Area (hectares) & & & 0.2 & 0.4 & 3 & 1 & 0.1 & 1 & 0.7 \\
\hline \multicolumn{10}{|l|}{ Vegetation type } \\
\hline & RuLu & Phragmites marsh & & & $x$ & & & & \\
\hline & SRhLu & Sedge herb swamp & & & $x$ & & & & \\
\hline & KoLu & Betula pubescens swamp & & & $x$ & & & & \\
\hline & OlLuSN & Extremely poor swampy tall sedge fen (LOCAL) & $x$ & & & & & & \\
\hline & LuN & Swamp fen & $x$ & & $x$ & & & & \\
\hline & LuRiSN & Swampy sedge fen with flark character (LOCAL) & & & $x$ & & & & \\
\hline & $\mathrm{MiRaR}$ & Minerotrophic Sphagnum fuscum bog (LOCAL) & & & $x$ & & $x$ & & \\
\hline & LuNK & Swampy Betula pubescens fen & $x$ & & $x$ & & & & \\
\hline & NigNK & Carex nigra Betula pubescens fen & $x$ & & & $x$ & & & \\
\hline & OISN & Extremely poor tall-sedge fen & & $x$ & & $x$ & & & \\
\hline & OISK & Extremely poor tall-sedge Betula pubescens fen & & & $x$ & $x$ & & $x$ & $x$ \\
\hline & MKgK & Thin-peated Vaccinium myrtillus spruce mire & & & & & $x$ & & \\
\hline & MeSK & Moderately poor tall-sedge Betula pubescens fen & & & $x$ & & & $x$ & \\
\hline & OISR & Extremely poor tall-sedge pine fen & & & $x$ & & $x$ & $x$ & \\
\hline & OlsphRiN & Extremely poor Sphagnum flark fen & & & & & $x$ & & $x$ \\
\hline & OlLkR & Extremely poor short sedge pine fen & & & $x$ & & $x$ & $x$ & $x$ \\
\hline & OlKaSN & Extremely poor Sphagnum papillosum tall-sedge fen & & & & $x$ & & & \\
\hline & $\mathrm{RaR}$ & Sphagnum fuscum bog & & & & & & $x$ & $x$ \\
\hline & OlLkN & Extremely poor low-sedge fen & & $x$ & & & & & \\
\hline & PsR & Carex globularis pine mire & & & & & & X & \\
\hline & $\mathbb{R}$ & Dwarf-shrub pine bog & & & & & & & $x$ \\
\hline
\end{tabular}


types include lawn-dominated extremely poor fen types, the Sphagnum papillosum pine fen (KaR), the short-sedge pine fen (LkR) and the Sphagnum papillosum fen (KaN) (Table 7), which occupy the bulk of peripheral lawns (Laitinen et al. 2007) of several local wetland types among evolving mire complexes. The aapa mire chronosequence of Ryöskäri-Nikkilänaapa-Kairavaara (0-70 m a.s.I.), $15 \mathrm{~km}$ north of the study area, shows a pattern resembling that of Nyby. There the focus of Sphagnum papillosum is at the altitudes of 30-50 $\mathrm{m}$ a.s.l. (Rehell \& Laitinen 2014). Mid-boreal focus of the above-mentioned vegetation types is trivial and climatically expected, as the mid-boreal zone of
Finland is characterized by the lawn in mires, while the north-boreal zone is characterized by the flark level according to Ruuhijärvi (1960, 1983) and Eurola et al. (1984). Above-mentioned vegetation types avoiding the lowest altitudes represent classic mire expanse vegetation (Weissmoore, Weissmoor-Reisermoore, Ruuhijärvi 1960; Eurola 1962), whereas their lack from the lowest altitudes partly reflects the major gradient in the whole group of Nyby wetlands, the mire margin to expanse gradient.

Also the vegetation reported highly boreal as contrast to nemoral vegetation (Rydin et al. 1999b) avoid the lowest altitudes in Nyby. Carex

Table 4. Local Wetland Group $\mathrm{C}$ in the inland near the seaside in Nyby area (6-18 $\mathrm{m}$ a.s.l., below 1-6 hectares). For each wetland location (see Fig. 1 for place names), Major Vegetational Wetland Group (MVWG), Major Topographic Wetland Group (MTWG), Local Wetland Type (LWT), altitude, area and vegetation types are shown. Wetlands are arranged according to vegetation type composition ( 2 swampy mire vegetation, 3 mire expanse vegetation), and altitude within each major group. Vegetation types are arranged according to their mean altitude in the whole material. LWTs are 0 transitional mires (not classified into LWTs), 5 unpatterned swampy aapa mires, and 6 unpatterned lawn aapa mires. For summary of LWTs, see Table 1. LOCAL refers to a local community.

\begin{tabular}{|c|c|c|c|c|c|c|c|c|}
\hline Wetland location & & & 24 & 25 & 21 & 32 & 33 & 30 \\
\hline (MVWG & & & 2 & 2 & 2 & 3 & 3 & 3 \\
\hline MTWG & & & II & II & II & II & II & II \\
\hline LWT & & & 5 & 5 & 5 & 0 & 0 & 6 \\
\hline Altitude (m a.s.l.) & & & 6 & 6 & 7 & 11 & 13 & 18 \\
\hline Area (hectares) & & & 3 & 2 & 6 & 3 & 0.5 & 4 \\
\hline \multicolumn{9}{|l|}{ Vegetation type } \\
\hline & SRhLu & Sedge herb swamp & & & $x$ & & & \\
\hline & TeLu & Alnus glutinosa swamp & $x$ & & & & & \\
\hline & HaLu & Alnus incana swamp & $x$ & & & & & \\
\hline & LuN & Swamp fen & $x$ & $x$ & $x$ & & & \\
\hline & MeLuRiSN & Moderately poor swampy sedge fen with flark character (LOCAL) & & & $x$ & & & \\
\hline & MeSphRiN & Moderately poor Sphagnum flark fen & $\mathrm{X}$ & & & $\mathrm{X}$ & & \\
\hline & NigNK & Carex nigra Betula pubescens fen & & & $x$ & & & \\
\hline & MeSphRiNR & Moderately poor Sphagnum flark pine fen & & & & & $\mathrm{X}$ & \\
\hline & LuNK & Swampy Betula pubescens fen & $\mathrm{X}$ & & & & & \\
\hline & OISN & Extremely poor tall-sedge fen & $x$ & $x$ & $x$ & $x$ & & \\
\hline & OISK & Extremely poor tall-sedge Betula pubescens fen & $x$ & & $x$ & & & $x$ \\
\hline & MKgK & Thin-peated Vaccinium myrtillus spruce mire & & & $x$ & $x$ & $x$ & \\
\hline & MeSK & Moderately poor tall-sedge Betula pubescens fen & & $x$ & $x$ & $x$ & & \\
\hline & OlSphRiNR & Extremely poor Sphagnum flark pine fen & & & & & & $\mathrm{X}$ \\
\hline & OISR & Extremely poor tall-sedge Betula pubescens fen & & & & & $x$ & $x$ \\
\hline & MeRuRiN & Moderately poor mud bottom flark fen & $\mathrm{X}$ & $\mathrm{X}$ & $\mathrm{X}$ & & & \\
\hline & OlSphRiN & Extremely poor Sphagnum flark fen & $\mathrm{X}$ & & & $\mathrm{X}$ & & $\mathrm{X}$ \\
\hline & MeSN & Moderately poor tall-sedge fen & & $\mathrm{X}$ & & & & $\mathrm{X}$ \\
\hline & OlLkR & Extremely poor low-sedge pine fen & $x$ & & $x$ & & & $x$ \\
\hline & OlKaSN & Extremely poor Sphagnum papillosum tall-sedge fen & & & $x$ & $x$ & & \\
\hline & RhK & Herb grass spruce mire & & & $x$ & & & \\
\hline & RaR & Sphagnum fuscum bog & & & & & & $\mathrm{X}$ \\
\hline & OlKaN & Extremely poor Sphagnum papillosum low-sedge fen & & & $\mathrm{X}$ & & & $\mathrm{X}$ \\
\hline & OlLkN & Extremely poor low-sedge fen & & & $x$ & & & \\
\hline & MeLkN & Moderately poor low-sedge fen & & & $x$ & & & \\
\hline & MeKaSN & Moderately poor Sphagnum papillosum tall-sedge fen & & & & $\mathrm{X}$ & & $\mathrm{X}$ \\
\hline & MeSR & Moderately poor tall-sedge pine fen & & & & $x$ & & \\
\hline
\end{tabular}


Table 5. Local Wetland Group D in central inland in Nyby area (10-30 m a.s.I., 4-82 hectares). For each wetland location (see Fig. 1 for place names), Major Vegetational Wetland Group (MVWG), Major Topographic Wetland Group (MTWG), Local Wetland Type (LWT), altitude, area and vegetation types are shown. Wetlands are arranged according to vegetation type composition (2 swampy mire vegetation, 3 mire expanse vegetation), and altitude within each major group. Vegetation types are arranged according to their mean altitude in the whole material. LWTs: 5 unpatterned swampy aapa mires, 6 unpatterned lawn aapa mires, 7 unpatterned flark aapa mires, 8 semi-patterned aapa mires and 10 patterned aapa mires. For summary of LWTs, see Table 1. LOCAL refers to a local community.

\begin{tabular}{|c|c|c|c|c|c|c|c|c|c|c|}
\hline Wetland location & & & 31 & 26 & 27 & 28 & 29 & 35 & 38 & 36 \\
\hline MVWG & & & 2 & 3 & 3 & 3 & 3 & 3 & 3 & 3 \\
\hline MTWG & & & II & II & II & II & II & II & II & II \\
\hline LWT & & & 5 & 6 & 6 & 6 & 7 & 7 & 8 & 10 \\
\hline Altitude (m a.s.l.) & & & 17 & 11 & 13 & 16 & 18 & 22 & 26 & 30 \\
\hline Area (hectares) & & & 14 & 4 & 5 & 6 & 19 & 82 & 22 & 43 \\
\hline \multicolumn{11}{|l|}{ Vegetation type } \\
\hline & SRhLu & Sedge herb swamp & $x$ & & & & & & & \\
\hline & LuNK & Swampy Betula pubescens fen & $x$ & & & & $x$ & $x$ & & $\mathrm{X}$ \\
\hline & NigNK & Carex nigra Betula pubescens fen & & & & & & $x$ & & \\
\hline & OmLkN & Ombrotrophic low-sedge bog & $x$ & & & & & $\mathrm{x}$ & & \\
\hline & OISN & Extremely poor tall-sedge fen & $x$ & $\mathrm{X}$ & & & $\mathrm{x}$ & $x$ & $x$ & \\
\hline & OISK & Extremely poor tall sedge Betula pubescens fen & & & & & & $x$ & & \\
\hline & RuRiLN & Intermediate mud bottom flark fen & $x$ & & & & & $x$ & & \\
\hline & PSKR & Carex globularis spruce pine mire & $x$ & & & & & & $x$ & \\
\hline & MKgK & Thin-peated Vaccinium myrtillus spruce mire & & & & & & $\mathrm{x}$ & & $x$ \\
\hline & MeSK & Moderately poof tall-sedge Betula pubescens fen & $x$ & & & & & $\mathrm{x}$ & $\mathrm{x}$ & $x$ \\
\hline & OISR & Extremely poor tall-sedge pine fen & & $x$ & & $\mathrm{x}$ & $\mathrm{x}$ & $\mathrm{x}$ & $x$ & $x$ \\
\hline & MeRuRiN & Moderately poor mud bottom flark fen & $x$ & $x$ & & & $x$ & $x$ & $x$ & $x$ \\
\hline & RuKuN & Mud bottom bog & & & & & & $\mathrm{x}$ & & \\
\hline & RuRiLNR & Intermediate mud bottom flark pine fen & & & & & & $x$ & & \\
\hline & LR & Rich pine fen (LOCAL) & & & & & & $\mathrm{x}$ & & \\
\hline & OlSphRiN & Extremely poor Sphagnum flark fen & $x$ & $x$ & $x$ & $x$ & $x$ & $\mathrm{x}$ & $X$ & $\mathrm{x}$ \\
\hline & MeSN & Moderately poor tall-sedge fen & & & & & $x$ & $x$ & & \\
\hline & OlLkR & Extremely poor short sedge pine fen & & $x$ & $\mathrm{X}$ & $\mathrm{x}$ & & $\mathrm{x}$ & $\mathrm{X}$ & $x$ \\
\hline & OlKaSN & Extremely poor Sphagnum papillosum tall-sedge fen & & $x$ & & $x$ & $x$ & $x$ & $\mathrm{x}$ & $x$ \\
\hline & SphKuN & Sphagnum hollow bog & & & & & & $x$ & & \\
\hline & $\mathrm{RaR}$ & Sphagnum fuscum bog & $x$ & $x$ & $x$ & & & $x$ & $\mathrm{x}$ & $x$ \\
\hline & OlKaN & Extremely poor Sphagnum papillosum low-sedge fen & & $\mathrm{x}$ & $\mathrm{X}$ & $\mathrm{x}$ & $\mathrm{x}$ & $\mathrm{X}$ & & $\mathrm{x}$ \\
\hline & OlLkN & Extremely poof low-sedge fen & & $\mathrm{x}$ & $\mathrm{x}$ & $\mathrm{x}$ & & $\mathrm{x}$ & $x$ & $\mathrm{x}$ \\
\hline & PsR & Carex globularis pine mire & & & $\mathrm{X}$ & $\mathrm{x}$ & & $\mathrm{x}$ & & \\
\hline & IR & Dwarf-shrub pine bog & & $\mathrm{x}$ & & & & & & \\
\hline & MeKaSR & Moderately poor Sphagnum papillosum tall-sedge pine fen & & & & & $\mathrm{x}$ & & & \\
\hline & MeKaSN & Moderately poor Sphagnum papillosum tall-sedge fen & & & & & $\mathrm{x}$ & $x$ & & $\mathrm{x}$ \\
\hline & OlRuRiN & Extremely poor mud bottom flark fen & & $\mathrm{X}$ & $\mathrm{X}$ & $\mathrm{X}$ & & $\mathrm{X}$ & $\mathrm{X}$ & \\
\hline & CaL & Rich Campylium stellatum fen & & & & & & $\mathrm{x}$ & & \\
\hline & MeSR & Moderately poor tall-sedge pine fen & & & & & & $\mathrm{x}$ & & \\
\hline & OlRiKaN & Extremely poor S. papillosum low-sedge fen with flark character & & $\mathrm{X}$ & & $\mathrm{x}$ & & $\mathrm{X}$ & $\mathrm{X}$ & \\
\hline & OIKaSR & Extremely poor Sphagnum papillosum tall-sedge pine fen & & & & & & & $x$ & \\
\hline & TR & Eriophorum vaginatum pine bog & & & & & & $\mathrm{x}$ & & \\
\hline & MeRuRiNR & Moderately poor mud bottom flark pine fen & & & & & & $\mathrm{x}$ & & \\
\hline & $\mathrm{KgR}$ & Thin-peated pine mire & & & & $x$ & & & & \\
\hline & OlKaNR & Extremely poor Sphagnum papillosum low-sedge pine fen & & $\mathrm{X}$ & & & $\mathrm{x}$ & & & \\
\hline & ScoRiL & Rich Scorpidium scorpioides flark fen & & & & & & $\mathrm{x}$ & & \\
\hline & SphLNR & Intermediate Sphagnum (lawn) pine fen & & & & & & $x$ & & \\
\hline & MeScomN & Moderately poor Sphagnum compactum low-sedge fen (MICRO) & & & & & & & & $\mathrm{X}$ \\
\hline & MeKaNR & Moderately poor Sphagnum papillosum low-sedge pine fen & & & & & & & & $\mathrm{x}$ \\
\hline & OlScomNR & Extremely poor Sphagnum compactum low-sedge pine fen & & & & & & & & $\mathrm{x}$ \\
\hline & MeKaN & Moderately poor Sphagnum papillosum low-sedge fen & & & & & & & & $x$ \\
\hline
\end{tabular}


globularis pine mire (PsR) (Table 7), representing a frequent boreal vegetation type characterizing acid areas (Kaakinen et al. 2008; Rydin et al. 1999b), is common in Nyby at the altitudes from 6 to $53 \mathrm{~m}$ a.s.l, occurring in small wetlands and in evolving mire complexes. The scattered occurrences of intermediate fens (LN) (Table 8) confine to still higher altitudes, mainly to altitudes from 43 to $53 \mathrm{~m}$ a.s.l. The high-altitude position of the intermediate Loeskypnum badium fen (LoebadLN) in Nyby partly agrees with the abundant occurrence of Loeskypnum badium at medium to high altitudes (15-50 m a.s.l) along the aapa mire chronosequence of Ryöskäri-Nikkilänaapa-Kairavaara (Rehell \& Laitinen 2014), where the rich and intermediate fens with mire margin vegetation, absent from the wetlands of Nyby, occupy low altitudes above the swamp belt (Rehell et al. 2012a, 2012 b). The high-altitude position of the intermediate Loeskypnum badium fens in mid-boreal Nyby area is additionally in agreement with the statement of Persson (1962) that the community represents classic mire expanse vegetation. The point for the Nyby study area is that this community does not seem to occupy its highly specific microsites until at the highest altitudes, within patterned aapa mires: increasing in mire expanse character of the vegetation was the main trend along increasing altitudes in Nyby. It is, however, remarkable that the microhabitas occupied by the community locate like habitats having groundwater influence, forming narrow lawns resembling micro soaks in the gently sloping proximal margins of fens, often surrounded by Sphagnum fuscum surfaces, as Ruuhijärvi (1960) states, and sometimes with micro soaks of Warnstorfia sarmentosa spring fens (WarnsarmLäN) in the vicinity. The latter, representing a poorly documented northern boreal community in the central Finnish Lapland (Laitinen et al. 2011) and a subalpine to alpine community in the western Italian alps (Miserere et al. 2003), represents almost the only sites with evident groundwater influence in Nyby. To conclude, the mire communities representing highly boreal vegetation in Nyby occur outside the lowest altitudes in the mid-boreal coastal lowland and either occupy scattered special patches of the sloping proximal margins of fens associated with groundwater influence (Quelligkeit, Ruuhijärvi 1960), or they occupy frequent, larger and flatter thin-peated treed areas (Bruchmoorigkeit,
Ruuhijärvi 1960; Eurola 1962) in the peripheries of mires. Both the directions of variation (Tuomikoski 1942, 1955) are avoided by the wetlands at the lowest altitudes in Nyby but are abundantly present in the wetlands at low altitudes (1.5-15 $\mathrm{m}$ a.s.l.) along the aapa mire chronosequence of Ryöskäri-NikkilänaapaKairavaara (Rehell et all. 2012a, 2012b; Rehell \& Laitinen 2014).

\section{Successional patterns}

General remarks and constraints in the material

In succession studies, the concept chronosequence is much used. For example Walker et al. (2010) state that chronosequences should be used only in cases when there is evidence that sites of different ages are following the same trajectory. In the wetlands of Nyby it seems that a couple of slightly different trajectories or stretches of trajectories appear among wetlands, including those within small bedrock basins and those within larger bedrock basins.

The approach used in this study allows for the reconstruction of the local wetland succession at a rough scale marked out by the MTWGs and the LWTs (Table 1), while the approach of Rehell et al. (2012a, 2012b) states for the initiation and the trajectory of specific mire surface levels in details. For the interpretation of the succession of the wetlands of Nyby, there are several constraints. Firstly, at the lowest altitudes, the bedrock basins large enough for the formation of mire complexes are lacking. Secondly, in the material the small wetlands at higher altitudes are lacking. Third notion is the same as for the hydrologic patterns: the material represents a sample including, however, the bulk of the wetlands in the study area. Finally, for the interpretation of the succession of the wetlands of Nyby, it is of some significance, into which MTWGs some critical LWTs are placed. LWT 5, called here unpatterned swampy aapa mires (Table 1), seems an intermediate between the small wetlands (MTWG I) and young successional stages of aapa mires (MTWG II) with the exception of mire 31 (Fig. 1), which is larger (14 ha) and locates at an altitude (18 $\mathrm{m}$ a.s.I.) higher than the rest of the wetlands in that group. We, however, also regard the small wetlands (2-6 ha) at low altitudes (4-7 m a.s.I.) in LWT 5 (Fig. 7) as a young successional stage of aapa mires because they have at least a 
Table 6. Local Wetland Group E at the highest altitude in the inland in Nyby (34-53 m asl., 14-185 hectares). For each wetland location (see Fig. 1 for place names), Major Vegetational Wetland Group (MVWG), Major Topographic Wetland Group (MTWG), Local Wetland Type (LWT), altitude, area and vegetation types are shown. Wetlands are arranged according to vegetation type composition (3 mire expanse vegetation), and altitude within each major group. Vegetation types are arranged according to their mean altitude in the whole material. LWTs are 8 semi-patterned aapa mires, 9 aapa Sphagnum fuscum bogs and 10 patterned aapa mires. For summary of LWTs, see Table 1. MICRO refers to a small-sized community.

\begin{tabular}{|c|c|c|c|c|c|c|c|c|c|c|c|}
\hline Wetland location & & & 34 & 37 & 39 & 40 & 43 & 41 & 42 & 44 & 45 \\
\hline MVWG & & & 3 & 3 & 3 & 3 & 3 & 3 & 3 & 3 & 3 \\
\hline MTWG & & & II & II & II & II & II & II & II & II & II \\
\hline LWT & & & 9 & 8 & 10 & 10 & 10 & 10 & 10 & 10 & 10 \\
\hline Altitude (m a.s.I.) & & & 34 & 39 & 43 & 44 & 45 & 50 & 51 & 52 & 53 \\
\hline Area (hectares) & & & 24 & 31 & 59 & 65 & 14 & 69 & 51 & 65 & 185 \\
\hline \multicolumn{12}{|l|}{ Vegetation type } \\
\hline & LuN & Swamp fen & & & & $x$ & $x$ & & & & \\
\hline & LuNK & Swampy Betula pubescens fen & & $\mathrm{X}$ & & $\mathrm{X}$ & & & & & $\mathrm{X}$ \\
\hline & NigNK & Carex nigra Betula pubescens fen & & $x$ & & & & & & & \\
\hline & OmLkN & Ombrotrophic low sedge bog & $\mathrm{X}$ & & & & & & & & \\
\hline & OISN & Extremely poor tall-sedge fen & & $\mathrm{X}$ & & $\mathrm{X}$ & $\mathrm{X}$ & & & & \\
\hline & OISK & Extremely poor tall-sedge Betula pubescens fen & & $\mathrm{X}$ & & $\mathrm{x}$ & & & & & \\
\hline & RuRiLN & Intermediate mud bottom flark fen & & & $X$ & & & & & & \\
\hline & PsKR & Carex globularis spruce pine mire & & $\mathrm{X}$ & $\mathrm{X}$ & & & & & & \\
\hline & MKgK & Thin-peated Vaccinium myrtillus spruce pine mire & & & & & & $\mathrm{X}$ & & $x$ & $\mathrm{X}$ \\
\hline & MeSK & Moderately poor tall-sedge Betula pubescens fen & & & $\mathrm{X}$ & $\mathrm{X}$ & & & $\mathrm{X}$ & & $\mathrm{X}$ \\
\hline & OISR & Extremely poor tall-sedge pine fen & $X$ & $X$ & & & $X$ & $X$ & & & \\
\hline & MeRuRiN & Moderately poor mud bottom flark fen & & $x$ & $\mathrm{X}$ & $\mathrm{x}$ & $\mathrm{X}$ & $x$ & & $\mathrm{X}$ & $\mathrm{X}$ \\
\hline & OlSphRiN & Extremely poof Sphagnum flark fen & $\mathrm{X}$ & $X$ & $\mathrm{X}$ & $\mathrm{X}$ & $\mathrm{X}$ & $\mathrm{X}$ & $x$ & $X$ & $\mathrm{X}$ \\
\hline & MeSN & Moderately poor tall-sedge fen & & $\mathrm{X}$ & $\mathrm{X}$ & & $\mathrm{X}$ & & & & $\mathrm{X}$ \\
\hline & OlLkR & Extremely poor short sedge pine fen & $\mathrm{X}$ & $x$ & & $X$ & & $x$ & $x$ & $X$ & $x$ \\
\hline & OlKaSN & Extremely poor Sphagnum papillosum tall-sedge fen & $X$ & $x$ & $x$ & & $x$ & $x$ & $x$ & & \\
\hline & SphKuN & Sphagnum hollow bog & $\mathrm{x}$ & & & & & & & & \\
\hline & RhK & Herb-grass spruce mire & & $\mathrm{X}$ & & & & & & & $\mathrm{X}$ \\
\hline & RaR & Sphagnum fuscum bog & $\mathrm{X}$ & $\mathrm{X}$ & $\mathrm{X}$ & $\mathrm{X}$ & & & $\mathrm{X}$ & $\mathrm{X}$ & $\mathrm{X}$ \\
\hline & OlKaN & Extremely poor Sphagnum papillosum low-sedge fen & $\mathrm{X}$ & $x$ & & $x$ & $x$ & $x$ & $x$ & & $x$ \\
\hline & OlLkN & Extremely poof low-sedge fen & $\mathrm{X}$ & $\mathrm{X}$ & $\mathrm{X}$ & $\mathrm{X}$ & $\mathrm{X}$ & $\mathrm{X}$ & $\mathrm{X}$ & $\mathrm{X}$ & $\mathrm{X}$ \\
\hline & PsR & Carex globularis pine mire & $\mathrm{X}$ & $x$ & $x$ & $x$ & $x$ & $\mathrm{X}$ & $x$ & $x$ & $X$ \\
\hline & MeLkN & Moderately poor low-wedge fen & & & & $\mathrm{X}$ & & & & & $\mathrm{X}$ \\
\hline & IR & Dwarf-shrub pine bog & & & & $x$ & & & $x$ & & $x$ \\
\hline & MeKaSR & Moderately poor Sphagnum papillosum tall-sedge pine fen & & & & $x$ & $\mathrm{x}$ & $\mathrm{x}$ & & & $x$ \\
\hline & MeKaSN & Moderately poor Sphagnum papillosum tall-sedge fen & & & $\mathrm{X}$ & $\mathrm{X}$ & $\mathrm{X}$ & $\mathrm{X}$ & $\mathrm{X}$ & $\mathrm{X}$ & $\mathrm{X}$ \\
\hline & OlRuRiN & Extremely poor mud-bottom flark fen & $\mathrm{X}$ & $\mathrm{X}$ & $\mathrm{X}$ & & & & $\mathrm{X}$ & $\mathrm{X}$ & $\mathrm{X}$ \\
\hline & CaL & Rich Campylium stellatum fen (MICRO) & & & & & & & & & $\mathrm{X}$ \\
\hline & MeSR & Moderately poor tall-sedge pine fen & & $\mathrm{X}$ & $\mathrm{x}$ & & & & $\mathrm{x}$ & & $\mathrm{X}$ \\
\hline & OIRiKaN & Extremely poor S. papillosum low-sedge fen with flark character & $\mathrm{X}$ & $\mathrm{X}$ & $\mathrm{X}$ & $\mathrm{X}$ & & & & $\mathrm{X}$ & \\
\hline & OIKaSR & Extremely poor Sphagnum papillosum tall-sedge pine fen & & $\mathrm{X}$ & & & & $\mathrm{X}$ & & & \\
\hline & $\mathrm{TR}$ & Eriophorum baginatum pine bog & & & & $x$ & & & & & \\
\hline & MeRuRiNR & Moderately poor mud bottom flark pine fen & & & & $x$ & & & & & \\
\hline & KgR & Thin-peated pine mire & & $\mathrm{X}$ & & & & & & & $\mathrm{x}$ \\
\hline & OIKaNR & Extremely poor Sphagnum papillosum low-sedge pine fen & & & & $\mathrm{X}$ & & & $\mathrm{X}$ & & $\mathrm{X}$ \\
\hline & ScoRiL & Rich Scorpidium scorpioides flark fen & & & $\mathrm{X}$ & & & & & & \\
\hline & SphLNR & Intermediate Sphagnum (lawn) pine fen & & & $\mathrm{X}$ & & & & & & $X$ \\
\hline & MeKaNR & Moderately poor Sphagnum papillosum low-sedge pine fen & & & & & & & $\mathrm{X}$ & & $\mathrm{X}$ \\
\hline & RhKgK & Thin-peated herb spruce mire & & & & & & & $\mathrm{x}$ & & \\
\hline & OIScomNR & Extremely poor $S$. compactum pine fen (MICRO) & & & & $x$ & & & $\mathrm{x}$ & & $x$ \\
\hline & LhK & Thin-peated rich spruce mire (MICRO) & & & & & & & & & $x$ \\
\hline & MeKaN & Moderately poor Sphagnum papillosum low-sedge fen & & & $\mathrm{X}$ & $\mathrm{x}$ & & & $\mathrm{X}$ & & $\mathrm{X}$ \\
\hline & OIRuRiNR & Extremely poor mud bottom flark pine fen & & & & & & & & & $\mathrm{x}$ \\
\hline & WarnsarmLäN & Warnstorfia sarmentosa spring fen (MICRO) & & & $\mathrm{X}$ & $X$ & & & $\mathrm{X}$ & & \\
\hline & RuRiL & Rich mud bottom flark fen & & & & $x$ & & & & & \\
\hline & LoebadLN & Intermediate Loeskypnum badium fen & & & $\mathrm{x}$ & $\mathrm{X}$ & & & & & $x$ \\
\hline & SphLN & Intermediate Sphagnum (lawn) fen & & & $\mathrm{x}$ & $x$ & & & & & $x$ \\
\hline & MeRhyfusRuRiN & Moderately poor mud bottom flark fen dominated by $R$. fusca & & & $x$ & $x$ & & & & & $x$ \\
\hline & RevRiL & Rich Scorpidium revolvens flark fen (MICRO) & & & $\mathrm{X}$ & $\mathrm{x}$ & & & & & \\
\hline & $\mathrm{OlS} \operatorname{com} N$ & Extremely poor Sphagnum compactum fen (MICRO) & & & $\mathrm{x}$ & & & & & & \\
\hline & KeLR & Rich mire expanse fen & & & $x$ & & & & & & \\
\hline & RhyfusRuRiLN & Intermediate mud bottom flark fen dominated by $R$. fusca & & & $\mathrm{X}$ & & & & & & \\
\hline
\end{tabular}


Table 7. Frequent vegetation types along the altitude gradient and across Major Topographic Wetland Groups (MTWGs) as well as Local Wetland Types (LWTs) in Nyby area. Vegetation types are arranged according to their average altitude in the whole material.

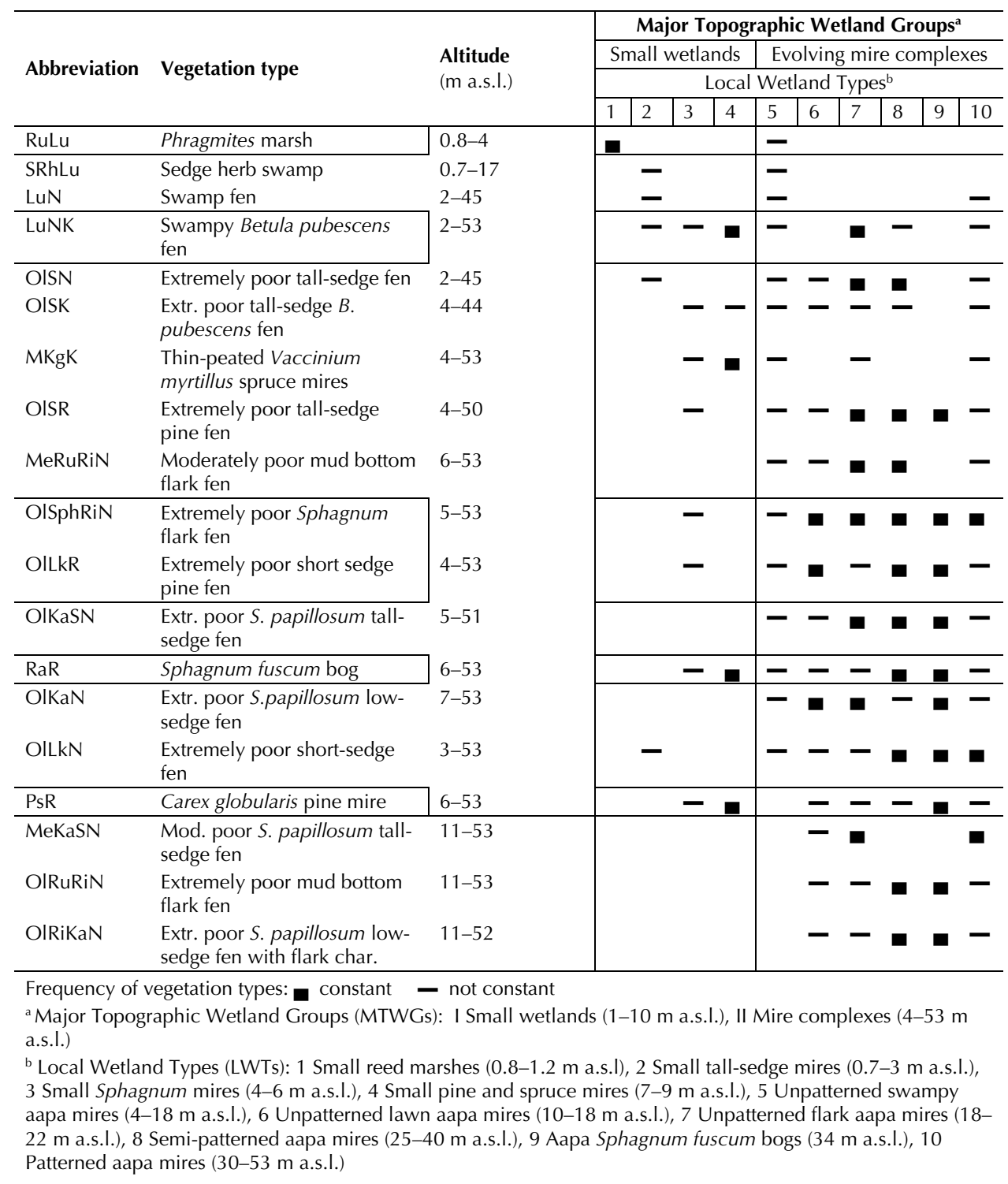

weak central-peripheral pattern characteristic of aapa mires. Unpatterned lawn aapa mires of Nyby (LWT 6), which are as small (4-6 ha) as the bulk of swampy aapa mires, are undisputed aapa mires because of their treeless mire expanse vegetation and the relatively well-developed central-peripheral topography (Laitinen et al. 2007).
Succession of wetlands in small bedrock basins

Part of the studied small wetlands (MTWG I) of Nyby seem to form a small successional group of its own. This concerns the wetlands near the seaside in LWG A (Fig. 7), northwest of Nyby site, where the wetlands of various LWTs form narrow 
Fig. Table 8. Unfrequent communities and vegetation types along the altitude gradient and across major topographic wetland groups (MTWGs) as well as Local Wetland Types (LWTs). The distribution of rare swampy communities and vegetation types (-Lu-), rare minerotrophic Sphagnum fuscum mires (MiRaR), intermediate fen types (-LN-), spring fen types (-LäN) and rich fen types (-L) are shown. Vegetation types are arranged according to their average altitude in the whole material.

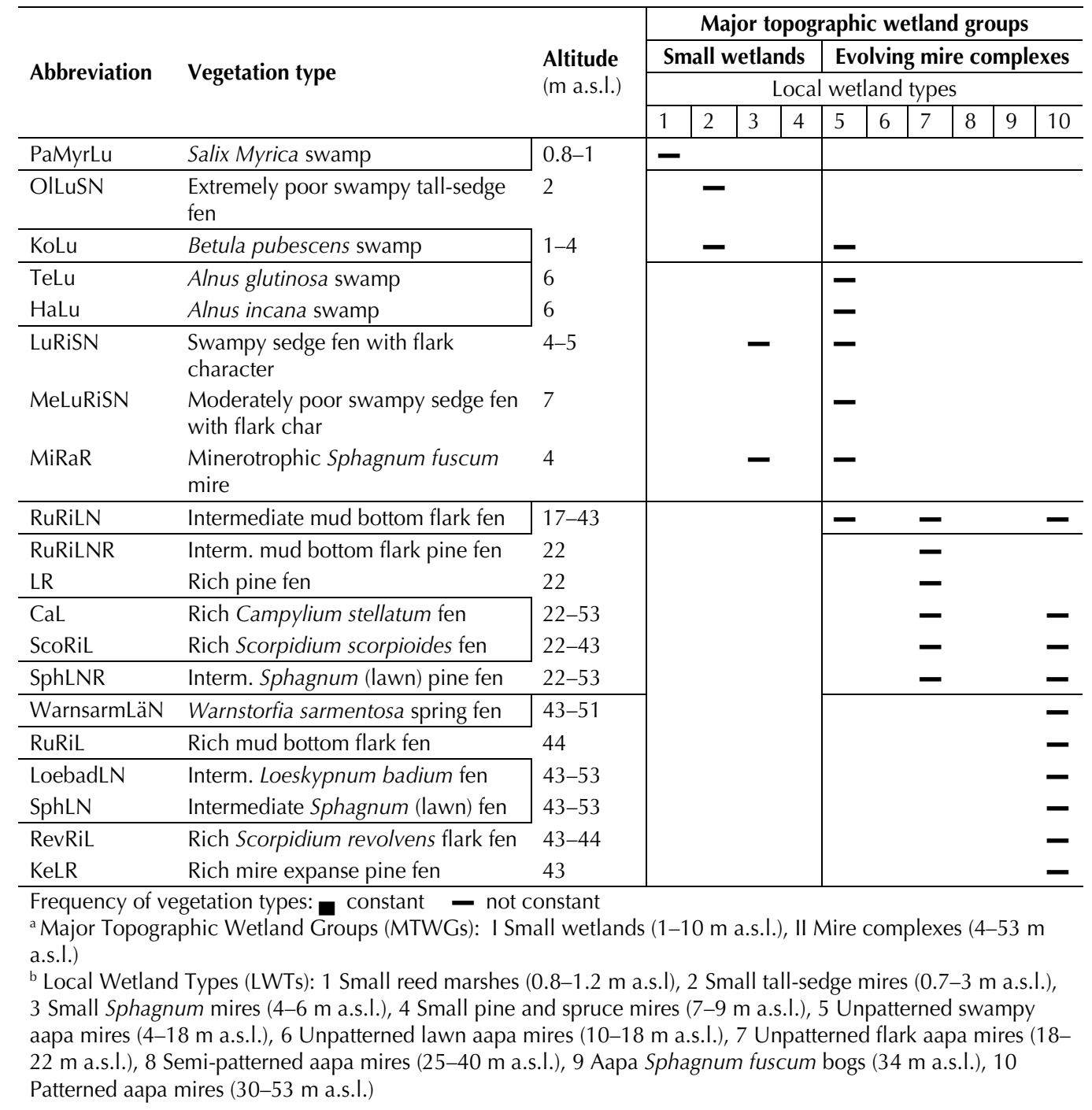

belts along increasing altitude (1-10 $\mathrm{m}$ a.s.I.), and where the local bedrock topography does not allow the present minute wetlands to enlarge considerably in the future, unlike in evolving boreal mire complexes in larger bedrock basins (Bauer et al. 2003) with larger catchment areas. Those small wetlands show a possible successional pathway along the altitude gradient across all the local wetland types from small reed marshes (LWT 1) (0.8-1.2 $\mathrm{m}$ a.s.l.) and small tall sedge mires (LWT 2) (0.7-3 m a.s.I.) to small Sphagnum mires (LWT 3) (4-6 $\mathrm{m}$ a.s.l.) and to small pine and spruce mires (LWT 4) (7-9 m a.s.I.). Small reed marshes (LWT 1) and partly small tall-sedge mires (LWT 2) 
of Nyby correspond to swamps (Sumpfmoore) of Brandt (1948) in the coast of the raised bog zone, while the small tall-sedge mires (LWT 2) partly correspond to Recurvum fens (Recurvum-Weissmoore) of Brandt (1948) characterized by an invasion of Sphagnum to swamps, later also the occurrence of Betula pubescens (swampy birch fens, LuNK, in Nyby wetlands). Small Sphagnum mires (LWT 3) of Nyby, which are currently experiencing both the appearance of the Sphagnum flark level with mire expanse vegetation (see Rehell et al. 2012b) and the change towards a poorer state along the poor-rich gradient (Tahvanainen 2004, 2011), do not seem to have a counterpart in the succession of mires in the raised bog zone (Brandt 1948). This is natural as the minerotrophic flark level with mire expanse vegetation is a feature characteristic of mires in the aapa mire zone (Ruuhijärvi 1960). Small Sphagnum mires (LWT 3) of Nyby only show that also in the succession of small wetlands (MTWG I), a feature of evolving mire complexes (MTWG II), the appearance of the flark level, weakly appears. Small pine and spruce mires (LWT 4) of Nyby, which represent the successional stage at the highest altitude $(7-9 \mathrm{~m}$ a.s.I.) along the succession of small wetlands present in the material, perhaps have a counterpart in Ledum mires of Brandt (1948) at the altitudes of 5 to $10 \mathrm{~m}$ a.s.I. To conclude the trajectory among the coastal group (MTWG I) of small wetlands northwest of Nyby site, it seems that it highly reflects the mire margin (swamps) to expanse gradient, which was shown as the major gradient for the whole group of 45 wetlands in Nyby. The above mentioned circumstance refers to the option that mire expanse vegetation within the succession of those minute mires $(0.1-1$ ha) is achieved during a time period shorter than (at lower altitudes than) in the mire complexes of Nyby, probably because of the smaller amounts of nutrients provided by the minute catchment areas surrounded by the small wetlands. Roughly speaking, considering only the major gradient at a high generalization level, it seems as if the aapa mires, during a longer time period, follow the trajectory of the small wetlands.

We hypothesized that the succession of small wetlands differs from that of aapa mires with regard to vegetation type composition and peatland morphology. Observations largely support this presumption. Firstly, evidence from the vegetation type composition agrees with this presumption, as locally rare vegetation types highly differed with regard to successional groups, and only locally common vegetation types were for the most part common to both the successional groups. Secondly, evidence from peatland morphology mainly supports the concept of the difference between the succession of small wetlands vs. that of aapa mires. In minute depressions there is no space for a peatland to form the complicated water-flow-dependent macro and microtopography characterized by climatic mire complex types (Ruuhijärvi 1960; Eurola 1962; Seppä 2002). Sphagnum fuscum surfaces, however, develop in both cases. In the successional group of small wetlands, Sphagnum fuscum surfaces finally occupy the mire centers in small pine and spruce mires (LWT 4, LWG A) (Fig. 7) like in raised bogs, referring to the oligocentral development of mires according to Ivanov (1981), while in aapa mires they occupy the peripheries of mire complexes referring to the oligoperipheral mire complex development of Ivanov (1981). In Kvarken archipelago, in the southern boreal zone, the bulk of mires are at altitudes $(0-10 \mathrm{~m}$ a.s.l.) the same as the studied small wetlands of Nyby according to Harju (2008), who states that the mires (of several hectares) commonly develop into short sedge fens (LkN), while also Sphagnum fuscum surfaces are achieved at $10 \mathrm{~m}$ a.s.l. or even below. The slightly larger size of the mires described by Harju (2008) in comparison with the minute mires northwest of Nyby site suggest that intermediates between small wetlands and mire complexes are common (see the mire complex type of the land uplift coast of the Bothnian Bay, Auer 1951).

\section{Succession of wetlands in larger bedrock basins}

In the wetlands of Nyby it seems that more than one slightly different trajectories or stretches of trajectories appear among wetlands in bedrock basins large enough to allow the formation of mire complexes. It seems to be crucial for the trajectory of a mire complex if the bedrock basin is located in the central or peripheral parts of a larger catchment area. This location accordingly serves as an ultimate cause for the successional trajectory. Relative altitudes effect the general water flow pattern in the landscape, and the water flow pattern with the rate of the flow of mire water in each point (Ivanov 1981; Seppä 2002; Laitinen et al. 2007), associated with well-known mireecological factors and gradients (e.g. Sjörs 1948; Eurola et al. 1984; Tahvanainen 2004, 2011; Laitinen et al. 2008b, 2008a) directly effect on 
plants and plant communities. Because the locations of the mire basins in catchment areas are decisive in the study area, such trajectories represent location-related successional pathways.

\section{a) Flark aapa mires}

The most evident location-related successional pathway among those mire complexes, which originally (before lateral site expansion) mainly locate in the central parts of larger catchment areas, is shown by the transition along the altitude gradient across the whole set of flark aapa mires (LWTs $5,7,8,10)$ (Fig. 7). It is precisely the question of the trajectories of the central basins (Laitinen et al. 2007) of those mire complexes. Surface water influence (Sumpfigkeit, Ruuhijärvi 1960) appears in the youngest successional stage of this set (unpatterned swampy aapa mires, LWT 5), as in those small wetlands, which are located in the same way in the central parts of catchment areas. The actual initial stages of aapa mires are lacking in Nyby because of the lack of bedrock basins large enough at the lowest altitudes (cf. the study area of Rehell et al. 2012a, 2012b). Unpatterned flark aapa mires (LWT 7) (18-22 m a.s.l.) are early flark aapa mires with mire expanse vegetation but with a lack of strings in central basins. Semi-patterned aapa mires (LWT 8) (25-40 m a.s.I.) are semi-mature flark aapa mires, which have poorly discernible strings in central basins, and patterned aapa mires (LWT 10) (30-53 $\mathrm{m}$ a.s.l.) are the mature stages of flark aapa mires with clearly discernible strings in central basins. It must be stressed that the lack of the patterning in wet central basins of an aapa mire may alternatively be due to the young successional age of the site (Rehell et al. 2012a, 2012b) or a weak flow of mire water caused by a highly flat substratum of a certain part of the flark area (Laitinen et al. 2007). Accordingly, the state of the patterning in the central basins of mature aapa mires may vary within the frames of one and the same mire complex even so that those variations in the patterning are striking in some of the largest mature aapa mires of the lowland at higher altitudes (Hirvisuo, $120 \mathrm{~m}$ a.s.l., Laitinen et al. 2005). Also outlet fens (Laitinen et al. 2007) with a high rate of flow of the mire water and an exceptionally dense flark-string pattern totally confine to mature aapa mires in Nyby (to distal parts of mires 41 and 42) (Fig. 1). It seems that at a still higher altitude (75 $\mathrm{m}$ a.s.l., Hoikkasuo, Laitinen et al. 2007), the dense transverse patterning (of stings and flaks) in outlet fens even turns into an indistinct longitudinal patterning. It is not quite certain whether this topographic variation among outlet fens is due to the successional change (so related to time) or merely due to the present water-flow conditions (so related to hydrology). We conclude that the morphologic changes of aapa mire centers do not at all confine to young successional stages, as is also seen in the studies of Rehell et al. (2012a, $2012 b$ ), and that the increasing of the proportion of the mud bottom, the initiation and the formation of the flark string pattern and especially the change towards a higher diversity in the microtopography, characterize the trajectory of central basins of aapa mires.

\section{b) Mire systems (mixed complexes) and bog complex types}

Nyby area provides additional examples of evolving mire systems (Heikkilä et al. 2001; see also Laitinen et al. 2007), which include both an aapa mire part and a bog complex part. Such systems, which are nowadays regarded fairly common in Finland (Heikkilä et al. 2006), were called mixed complexes by Tolonen (1967). Transition from small unpatterned lawn aapa mires 26, 27 and 28 (LWT 6) to the aapa Sphagnum fuscum bog Jäkäläsuo (LWT 9, mire 34) (Fig. 1, 7), in which the bog part is dominant, suggests a possible locationrelated successional stretch at catchment divides at relatively low altitudes (10-34 m a.s.l.). That stretch represents a change from a stage of young aapa mire with extremely poor fens to a stage of an unpatterned Sphagnum fuscum bog. Instead, patterned sloping bogs (eccentric bots) near the study area confine to higher altitudes (above $60 \mathrm{~m}$ a.s.l.), referring perhaps to a longer time period taken by the succession of that bog complex type. In the study area of Brandt (1948), in the (climatic) southboreal concentric Kermi raised bog zone in Finland (Eurola 1962), there is a narrow coastal belt at the altitudes from 10 to $18 \mathrm{~m}$ a.s.l., where treeless Sphagnum fuscum bogs are abundant, while more or less mature concentric Kermi raised bogs begin to occur above that belt (18 $\mathrm{m}$ a.s.l. and above it). It has been hypothesized that unpatterned Sphagnum fuscum bogs on the coast of the Gulf of Bothnia represent younger stages of Kermi raised bogs (Kaakinen et al. 2008).

As the wetland succession in general (Zweig \& Kitchens 2009), the succession of flark aapa mires 
may have multiple pathways created by hydrology and other factors. On air photos, the minerotrophic lawn-dominated peripheral part in the western side of Ulkusuo mire (number 35) (22 m a.s.I.) (Fig. $1,7)$ seems a successional counterpart to the patterned sloping bog with Kermis in the western side of Iso Heposuo mire at the altitude of $60 \mathrm{~m}$ a.s.l., two km north of the Nyby study area. This example of a successional stretch implies that an area up to an altitude about $60 \mathrm{~m}$ a.s.l. in the lowland around Nyby, forms a successional belt, in which mire systems, as called by Heikkilä et al. (2001) (see also Laitinen et al. 2007), are so far only forming. We conclude that two different trajectories characterize evolving lawn-flark aapa mires (Laitinen et al. 2007; Eurola et al. 2015) represented by Ulkusuo, and the trajectory of the central basins seems primary while that of the peripheral parts seems secondary, because the latter trajectory is probably mainly associated with the mire complex parts, which are results of the lateral site expansion of mire complexes (Bauer et al. 2003; Rehell et al. 2012a, 2012b). The trajectory of the aapa-mire peripheral parts (peripheral lobes, Laitinen et al. 2007 ) is characterized by a slow process of ombrotrophication (Tahvanainen 2011), while actual bogs (as complex parts of evolving mire systems) are only formed in hydrologically most beneficial sites at evident catchment divides.

\section{Conclusion}

The results of this study highlight two general points in boreal peatland succession. One, the sizes of bedrock basins and the sizes of their catchment areas affect the peatland succession so that partly different succession sequences may occur in areas with small mire basins and in areas with larger mire basins. Two, the locations of mire basins either in the peripheral or central parts of larger catchment areas also affect the peatland trajectories. Additionally, there are some peculiar features in Nyby related to wetland succession. Firstly, only stretches of successional sequences can be shown. The circumstance is caused by the coastal topography with various sub-areas in rugged bedrock terrain. Instead, the Ryöskäri till area and the Hailuoto sand area in the same lowland at the Bothnian Bay (Rehell et al. 2012a, 2012b) show uniform sequences of evolving aapa mires in topographically uniform beds. Secondly, the highly scarce rich fens of Nyby confine to high altitudes in the lowland and represent mire expanse vegetation. In Ryöskäri, instead, occur also rich fens with mire margin vegetation at low altitudes. Thirdly, the spruce mire influence (Bruchmoorigkeit, Ruuhijärvi 1960) and especially the groundwater influence (Quelligkeit, Ruuhijärvi 1960) appear to a lesser extent in Nyby, perhaps partly relating to the bedrock quality and to the abundance of rock outcrops and a shallow till layer in Nyby. Our research does not highlight diversity chances along succession or along increasing altitudes generally in the lowland. Diversity research with the richness (the number) of vegetation types in wetlands at different altitudes and of different sizes may provide a future research need of coastal wetlands.

\section{ACKNOWLEDGEMENTS}

Field work was funded as a part of the Wetlands Program for Oulu and Kainuu Regions in the Council of Oulu Region. We sincerely thank Ismo Karhu, the supervisor of the project, for providing us with the material. We also thank Jan Hjort from the Department of Geography, University of Oulu, for a short preliminary discussion before the study, Tauno Ulvinen from the Botanical Museum of Oulu, for checking some mosses, and two anonymous reviewers for structuring the text.

\section{REFERENCES}

Aario L 1932. Pflanzentopographische und paläogeographische Mooruntersuchungen in N-Satakunta. Fennia 55: 1, 1-179.

Alalammi P (ed) 1990. Atlas of Finland. Folio 123126. Geology. National Board of Survey, Geographical Society of Finland, Helsinki.

Auer V 1951. Suot. In Granö JG, Jurva R, Keränen J, Kujala V, Laitakari A, Pesonen U, Kalaja P \& Kanerava E (eds). Suomen maantieteen käsikirja [Handbook of the geography of Finland]. Fennia 72, 211-230.

Bauer IE, Gignac LD \& Vitt DH 2003. Development of a peatland complex in boreal western Canada: lateral site expansion and local variability in vegetation succession and long-term peat accumulation. Canadian Journal of Botany 81: 8, 833-847. http://dx.doi.org./10.1139/b03-076.

Brandt A 1948. Über die Entwicklung der Moore im Küstengebiet von Süd-Pohjanmaa am Bottnischen Meerbusen. Annales Botanici Societatis Zoologicae Botanicae Fennicae Vanamo 23: 4, 1-134.

Chase JM, Kraft NJB, Smith KG, Vellend M \& Inouye BD 2011. Using null models to disentangle variation in community dissimilarity from variation in alpha-diversity. Ecosphere 2: 2, 1-11. 
http://dx.doi.org./10.1890/ES10-00117.1.

Elveland J 1976. Myrar på Storön vid Norrbottenkuysten [Coastal mires on the Storön peninsula, Norrbaotten, N Sweden]. Wahlenbergia 3, 1-272. (in Finnish with English summary)

Eurola S 1962. Über die Regionale Einteilung der südfinnischen Moore. Annales Botanici Societatis Zoologicae Botanicae Fennicae Vanamo 33: 2, 1-124.

Eurola S \& Kaakinen E 1978. Suotyyppiopas [Guide to mire site types]. WSOY, Porvoo.

Eurola S \& Kaakinen E 1979. Ecological criteria of peatland zonation and the Finnish mire site type system. In Kivinen E, Heikurainen L \& Pakarinen P (eds). Classification of peat and peatlands, 20-32. International Peat Society, Hyytiälä.

Eurola S \& Vorren K-D 1980. Mire zones and sections in North Fennoscandia. Aquilo Serie Botanica 17, 39-56.

Eurola S, Hicks S \& Kaakinen E 1984. Key to Finnish mire types. In Moore P (ed). European mires, 11117. Academic Press, London.

Eurola S, Huttunen A \& Kukko-oja K 1995. Suokasvillisuusopas [Mire vegetation guide]. Oulanka Reports $14,1-85$.

Eurola S, Huttunen A, Kaakinen E, Kukko-oja K, Saari V \& Salonen V 2015. Sata suotyyppiä. Opas Suomen suokasvillisuuden tuntemiseen [Hundred mire site types. Guide to the Fínnish mire vegetation]. Thule-instituutti, Oulangan tutkimusasema, Oulun yliopisto, Oulu. (in Finnish)

Gonzáles-Megías A, Gómez M \& Sánchez-Piňero 2007. Diversity - habitat heterogeneity relationships at different spatial and temporal scales. Ecography 30: 1, 31-41. http://dx.doi.org/10.1111/j.0906-7590.2007.04867.x.

Harju A 2008. Maankohoamisrannikon nuorten soiden synty ja kehitys sekä kasvillisuuden sukkessiot Merenkurkun saariston alueella [Initiation and development of young mires and the succession of vegetation in Kvarken archipelago]. Unpublished Master thesis. Department of Geology, University of Turku.

Havas P 1961. Vegetation und Ökologie der ostfinnischen Hangmoore. Annales Botanici Societatis Zoologicae Botanicae Fennicae Vanamo 3: 1, 1-188.

Haylock MR, Hofstra N, Klein Tank AMG, Klok EJ, Jones PD \& New M 2008. A European daily highresolution gridded dataset of surface temperature and precipitation for 1950-2006. Journal of Geophysical Research (Atmospheres) 113, D20119. http://dx.doi.org/10.1029/2008JD010201.

Hämet-Ahti L 1981. The boreal zone and its biotic subdivision. Fennia 159: 1, 69-75.

Heikkilä R, Lindholm T \& Tahvanainen T (eds) 2006. Mires of Finland - Daughters of the Baltic Sea. The Finnish Environment 28. Finnish Environment Institute, Helsinki.

Heikkilä R, Kuznetsov O, Lindholm T, Aapala K, Antipin V, Djatshkova T \& Shevelin P 2001. Complexes, vegetation, flora and dynamics of Kauhaneva mire system, western Finland. The Finnish Environment 489. Finnish Environment Institute, Helsinki.
Hose GC, Bailey J, Stumpp C \& Fryirs K 2014. Groundwater depth and topography correlate with vegetation structure of an upland peat swamp, Budderoo plateau, NSW, Australia. Ecohydrology 7: 5, 1392-1402.

Ivanov KE 1981. Water movement in mirelands. Academic Press, London.

Kaakinen E, Kokko A, Aapala K, Kalpio S, Eurola S, Haapalehto T, Heikkilä R, Hotanen JP, Kondelin $H$, Nousiainen $H$, Ruuhijärvi R, Salminen $P$, Tuominen S, Vasander H \& Virtanen K 2008. Suot [Mires]. In Raunio A, Schulman A \& Kontula T (eds). Suomen luontotyyppien uhanalaisuus - Osa 2: Luontotyyppien kuvaukset [Assessment of threatened habitat types in Finland - Part 2: Habitat type descriptions], 145-256. Suomen Ympäristö 8. Suomen ympäristökeskus, Helsinki. (in Finnish with English summary)

Keddy PA 2000. Wetland ecology: principles and conservation. Cambridge University Press, Cambridge.

Kukko-oja K, Kärenlampi R, Rehell S, Repo S \& Siira O-P 2003. Maankohoamisrannikon luontoa Siikajoen Tauvosta Hummastinjärville. [Nature of the land uplift coast from Tauvo to Hummastinjärvi, Siikajoki]. Metsäntutkimuslaitoksen tiedonantoja 892.

Laine J \& Vasander H 2005. Suotyypit ja niiden tunnistaminen [Mire types and their identification]. Metsäkirjat, Helsinki.

Laitinen J, Heikkilä R \& Kondelin H 2011. Intermediate fen patches on a sloping rock outcrop in Koitelainen, Finnish Lapland. Mires and Peat 8: Art. 6 (Online: http://www.mires-and-peat.net/pages/ volumes/map0806.php)

Laitinen J, Rehell S \& Huttunen A 2005. Vegetationrelated hydrotopographic and hydrologic classification for aapa mires (Hirvisuo, Finland). Annales Botanici Fennici 42: 2, 107-121.

Laitinen J, Rehell S, Huttunen A, Tahvanainen T, Heikkilä R \& Lindholm T 2007. Mire systems of Finland with special view to aapa mires and their water flow pattern. Suo (Mires and peat) 58: 1, $1-26$.

Laitinen J, Kukko-oja K \& Huttunen A 2008a. Stability of the water regime forms a vegetation gradient in minerotroophic mire expanse vegetation of a boreal aapa mire. Annales Botanici Fennici 45: 342-358.

Laitinen J, Rehell S \& Oksanen J 2008b. Community and species responses to water level fluctuations with reference to soil layers in different habitats of mid-boreal mire complexes. Plant Ecology 194: 1, 17-36.

http://dx.doi.org/10.1007/s11258-007-9271-3 .

Legendre P \& Legendre L 2012. Numerical ecology. Elsevier, Amsterdam and Boston.

Leppälä M 2011. Successional changes in vegetation and carbon dynamics during boreal mire development. PhD thesis. University of Oulu, Oulu.

Lindholm T 2013a. Does the Finnish mire classification restrict oneself within its doctrine? Suo (Mires and peat) 64: 1, 29-42. (in Finnish with English summary) 
Lindholm T 2013b. Hundred years of mire complex studies in Finland. How the concepts have influenced our thinking? - A century form A. K. Cajander mire classic (1913): Studien über die Moore Finnlands. Suo (Mires and peat) 64: 2-3, 119-134. (in Finnish with English summary)

Locky DA, Baylye SE \& Vitt DH 2005. The vegetation ecology of black spruce swamps, fens, and bogs in southern boreal Manitoba, Canada. Wetlands 25: 3, 564-582. http://dx.doi.org/10.1872/02775212(2005)025\%5B0564:TVEOBS\%5D2.0;2.

Minchin PR 1987. An evaluation of relative robustness of techniques for ecological ordinations. Vegetatio 69, 89-107.

http://dx.doi.org/10.1007/BF00038690.

Miserere L, Montacchini F \& Buffa G 2003. Ecology of some mire and bog plant communities in the Western Italian Alps. Journal of Limnology 62: 1, 88-96. http://dx.doi.org/10.4081/jlimnol.2003.88.

Moen A 1999. National Atlas of Norway. Vegetation. Norway Mapping Authority, Hønefoss.

NLS 2010. Digital elevation models. National Land Survey of Finland, Helsinki.

Oksanen J 1990. Vegetation science in Finland. Journal of Vegetation Science 1: 2, 277-282. http://dx.doi.org/10.2307/3235665.

Oliver I, Broese EA, Dillon ML, Sivertsen D \& McNellie MJ 2013. Semi-automated assignment of vegetation survey plots within an a priori classification of vegetation types. Methods in Ecology and Evolution 4: 1, 73-81.

http://dx.doi.org/10.1111/j.2041-210x.2012.00258.x.

Pakarinen P 1976. Agglomerative clustering and factor analysis of south Finnish mire types. Annales Botanici Fennici 13: 1, 35-41.

Pakarinen P \& Ruuhijärvi R 1978. Ordination of northern Finnish peatland vegetation with factor analysis and reciprocal averaging. Annales Botanici Fennici 15, 147-157.

Persson $\AA$ 1962. Mire and spring vegetation in an area north of lake Torneträsk, Torne Lappmark, Sweden. Opera Botanica 6: 1, 1-187.

Raunio A, Schulman A \& Kontula T (eds) 2008. Suomen luontotyyppien uhanalaisuus - Osa 2: Luontotyyppien kuvaukset [Assessment of threatened habitat types in Finland - Part 2: Habitat type descriptions]. Suomen Ympäristö 8. Suomen ympäristökeskus, Helsinki. (in Finnish with English abstract)

R Core Team 2014. R: A language and environment for statistical computing. R Foundation for Statistical Computing, Vienna, Austria. <http://www.R-project.org/>

Rehell S \& Heikkilä R 2009. Aapasoiden nuoret sukkessiovaiheet Pohjois-Pohjanmaan maankohoamisrannikolla [Young successional stages of aapa mires on the land uplift coast of northern Ostrobothnia, Finland]. Suo (Mires and peat) 60: 1-2, 1-22. (in Finnish with English abstract)

Rehell S \& Laitinen J 2014. Vascular plant and moss species across successional mire basins on the land uplifg coast of Northern Ostrobothnia, Fin- land. Memoranda Societatis pro Fauna et Flora Fennica 90, 33-54.

Rehell S, Huttunen A, Kondelin H \& Laitinen J 2012a. Development of large-scale aapa mire hydrotopography on land-uplift coastland in northern Finland. The Finnish Environment 38, 39-50. Finnish Environment Institute, Helsinki.

Rehell S, Huttunen A \& Kondelin H 2012b. The development of patterning on a succession series of aapa-mire systems on the land-uplift coast of northern Ostrobothnia, Finland. The Finnish Environment 38, 51-64.

Ruuhijärvi R 1960. Über die Regionale Einteilung der Nordfinnischen Moore. Annales Botanici Societatis Zoologicae Botanicae Fennicae Vanamo 31: 1, $1-360$.

Ruuhijärvi R 1983. The Finnish mire types and their regional distribution. In Gore AJP (ed). Mires: swamp, bog, fen and moor. Ecosystems of the world, vol 4B, 47-67. Elsevier, Amsterdam.

Ruuhijärvi R \& Hosiaisluoma V 1988. Mires 1: 1000000. In Atlas of Finland, folio 141-143, Map Appendix 2. Natural Board of Survey \& Geographical Society of Finland, Helsinki.

Rydin H, Snoeijs P \& Diekman M (eds) 1999a. Swedish plant geography. Acta Phytogeographica Suecica 84. Svenska Växtgeografiska Sällskap, Uppsala.

Rydin H, Sjörs H \& Löfroth M 1999b. Mires. In Rydin $H$, Snoeijs P \& Diekman M (eds). Swedish plant geography, 91-112. Acta Phytogeographica Suecica 84. Svenska Växtgeografiska Sällskap, Uppsala.

Seppä H 2002. Mires of Finland: regional and local controls of vegetation, landforms, and long-term dynamics. Fennia 180: 1-2, 43-60.

Seppälä M 2005. The physical geography of Fennoscandia. Oxford University Press, Oxford.

Sjörs H 1948. Mire vegetation in Bergslagen, Sweden. Acta Phytogeographica Suecica 21. Svenska Växtgeografiska Sällskap, Uppsala. (in Swedish with English summary)

Svensson JS \& Jeglum JK 2000. Primary succession and dynamics of Norway spruce coastal forests on land-uplift ground moraine. Studia Forestalia Suecica 209. Sveriges lantbruksuniversitet, Uppsala.

Tahvanainen T 2004. Water chemistry of mires in relation to the poor-rich vegetation gradient a $n d$ contrasting geochemical zone of northeastern Fennoscandian Shield. Folia Geobotanica 39: 4, 353-369. http://dx.doi.org/10.1007/BF02803208.

Tahvanainen T 2011. Abrubt ombrotrophication of a boreal aapa mire triggered by hydrological disturbance in the catchment. Journal of Ecology 99: 2, 404-415.

http://dx.doi.org/10.1111/j.1365-2745.2010.01778.x.

Taipale K \& Saarnisto M 1991. Tulivuorista jääkausiin. Suomen maankamaran kehitys [From volcanos to ice ages. Development of the ground in Finland]. WSOY, Porvoo, Helsinki and Juva.

Tolonen K 1967. Über die Entwicklung der Moore im finnischen Nordkarelien. Annales Botanici Fennici 4: 3, 219-416. 
Tuittila E-S, Juutinen S, Frolking S, Väliranta M, Laine AM, Miettinen A, Seväkivi M-L, Quillet A \& Merilä P 2013. Wetland chronosequence as a model of peatland development. The Holocene 23: 1, 25-35. http://dx.doi.org/10.1177/0959683612450197.

Tuomikoski R 1955. Ruohoisuus ja luhtaisuus [Mesotrophy and surface water influence]. Suo (Mires and peat) 6, 1-18.

Tuomikoski R 1942. Untersuchungen über die Vegetation der Bruchmoore in Ostfinnland. I. Zur Methodik der pflanzensoziologischen Systematik.
Annales Botanici Societatis Zoologicae Botanicae Fennicae Vanamo 17, 1-203.

Walker LR, Wardle DA, Bardgett RD \& Carkson BD 2010. The use of chornosequences in studies of ecological succession and soil development. Journal of Ecology 98: 4, 725-736.

http://dx.doi.org/10.1111/j.1365-2745.2010.01664.x.

Zweig CL \& Kitchens WM 2009. Multi-state succession in wetlands: a novel use of state and transition models. Ecology 90: 7, 1900-1909.

http://dx.doi.org/10.1890/08-1392.1. 